\title{
Stratigraphic analysis of lake level fluctuations in Lake Ohrid: an integration of high resolution hydro-acoustic data and sediment cores
}

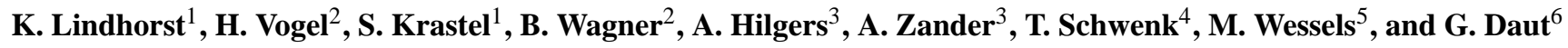 \\ ${ }^{1}$ Leibniz-Institute for Marine Sciences, IFM-GEOMAR, Cluster of Excellence: The Future Ocean, \\ Christian-Albrecht-University, Kiel, Germany \\ ${ }^{2}$ Institute for Geology and Mineralogy, University of Cologne, Cologne, Germany \\ ${ }^{3}$ Institute of Geography, University of Cologne, Cologne, Germany \\ ${ }^{4}$ Department of Geosciences at University of Bremen, Bremen, Germany \\ ${ }^{5}$ Institute for Lake Research, LUBW, Langenargen, Germany \\ ${ }^{6}$ Institute for Geography, Friedrich Schiller University, Jena, Germany
}

Received: 3 May 2010 - Published in Biogeosciences Discuss.: 20 May 2010

Revised: 21 October 2010 - Accepted: 3 November 2010 - Published: 10 November 2010

\begin{abstract}
Ancient Lake Ohrid is a steep-sided, oligotrophic, karst lake that was tectonically formed most likely within the Pliocene and often referred to as a hotspot of endemic biodiversity. This study aims on tracing significant lake level fluctuations at Lake Ohrid using high-resolution acoustic data in combination with lithological, geochemical, and chronological information from two sediment cores recovered from sub-aquatic terrace levels at ca. 32 and $60 \mathrm{~m}$ water depth. According to our data, significant lake level fluctuations with prominent lowstands of ca. 60 and $35 \mathrm{~m}$ below the present water level occurred during Marine Isotope Stage (MIS) 6 and MIS 5, respectively. The effect of these lowstands on biodiversity in most coastal parts of the lake is negligible, due to only small changes in lake surface area, coastline, and habitat. In contrast, biodiversity in shallower areas was more severely affected due to disconnection of today sublacustrine springs from the main water body. Multichannel seismic data from deeper parts of the lake clearly image several clinoform structures stacked on top of each other. These stacked clinoforms indicate significantly lower lake levels prior to MIS 6 and a stepwise rise of water level with intermittent stillstands since its existence as water-filled body, which might have caused enhanced expansion of endemic species within Lake Ohrid.
\end{abstract}

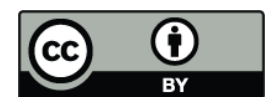

Correspondence to: K. Lindhorst (klindhorst@ifm-geomar.de)

\section{Introduction}

Within the terrestrial realm, ancient lakes are valuable archives providing crucial information on past climate, environmental conditions, and speciation among endemic taxa. With its inferred existence since the Pliocene, its location in the northern Mediterranean borderland and its high degree of endemic diversity (Stankovic, 1960; Albrecht and Wilke, 2008), Lake Ohrid (Fig. 1) provides a unique site to study climatic and environmental changes over long time scales and their possible links to evolutionary patterns.

As documented by numerous paleoclimate studies, the Mediterranean region has experienced large scale climate fluctuations over the last glacial-interglacial cycle (Allen et al., 1999, 2002; Bar-Matthews et al., 1999, 2000; Tzedakis et al., 2003; Martrat et al., 2004; Drysdale et al., 2005; Zanchetta et al., 2008; Vogel et al., 2010a). While information on past temperature variability at relatively high spatial resolution has become available during the past decade (Peyron et al., 1998; Allen et al., 1999; Martrat et al., 2004; Hayes et al., 2005; Marino et al., 2009), information on hydrological changes in the northern Mediterranean borderland is relatively sparse over long time scales (Tzedakis et al., 2003; Bordon et al., 2009). In order to gain a better understanding of the variability of hydrologic changes in this climate-sensitive region, additional spatially distributed paleoclimate records must be investigated. Ancient Lake Ohrid can provide such a record in the northern Mediterranean borderland with its sensitivity to recent and past climatic and environmental changes (Matzinger et al., 2006, 2007;

Published by Copernicus Publications on behalf of the European Geosciences Union. 


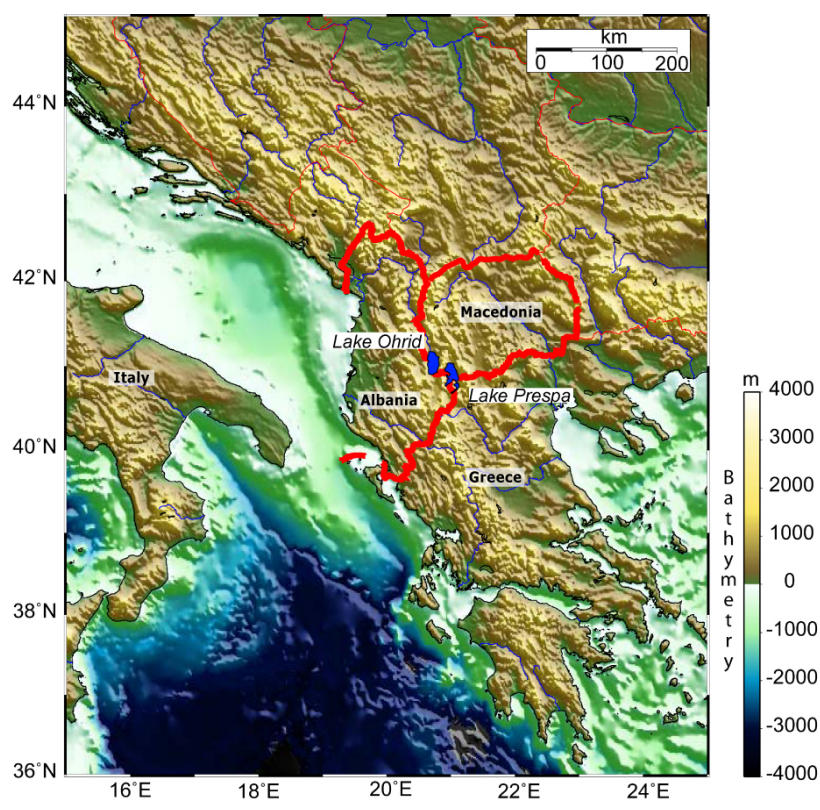

Fig. 1. Map of southern Europe with Lake Ohrid and its sister Lake Prespa located on the Balkan Peninsula.

Wagner et al., 2009; Vogel et al., 2010a). This promising location, however, has never been the subject of a quantitative study reconstructing past changes in hydrology. The detection and dating of subaquatic and subaerial terraces is a robust approach to infer past variations in the hydrological budget of an individual lake (Magny et al., 2009; Moernaut et al., 2010).

Among different possible climate-related factors affecting lacustrine ecosystems, changes of the water budget and associated lake level fluctuations have been identified as one important mechanism influencing biodiversity (Johnson et al., 1996; Sturmbauer et al., 2001; Genner et al., 2010). This is because lake level fluctuations are commonly accompanied with changes of the lake chemistry, surface area, coastline, and habitat distribution and thus directly affect species living in the lake (Martens, 1997). Many studies have investigated lake level fluctuations with special focus on climate change (Scholz and Rosendahl, 1988; D'Agostino et al., 2002; Anselmetti et al., 2006, 2009; Daut et al., 2010; Moernaut et al., 2010). In this study we try to minimize uncertainties in magnitude and timing of lake level changes by combining acoustic and sedimentological data in order to link it to biodiversity and speciation in Lake Ohrid.

Seismo-acoustic data provide images of continuous subsurfaces illustrating stacking trends, strata terminations, and geomorphology (Catuneanu et al., 2009). Depositional sequences can be subdivided into smaller stratigraphic units, termed system tracts, indicating their depositional regime during specific intervals of relative lake level changes (Posamentier et al., 1992; Hunt and Tucker, 1992; Allen and Allen,
2005). Shoreline trajectory describes the cross-sectional path of the shoreline as it migrates due to a change in lake level (Helland-Hansen and Martinsen, 1996). Three main factors determine the direction of the migration of the shoreline. These are the rate of relative lake level change, sediment supply, and basin physiography (Helland-Hansen and Martinsen, 1996). On a flat shelf area sediment is bypassed and falling relative lake level may cause the deposition of a set of down stepping prograding wedges in a forced regression system tract (FRST, Hunt and Tucker, 1992; Allen and Allen, 2005). Following a rise in lake level a Highstand System Tract (HST) with clinoform geometries evolves that onlaps onto the underlying sequence boundary in a landward direction (Allen and Allen, 2005). Clinoforms composed of topset, foreset and bottomset reflections are the fundamental building blocks of sedimentary basins (Gilbert, 1890; Pirmez et al., 1998).

While the magnitude of lake level change can be inferred relatively easily from the shoreline trajectory, dating of one particular stillstand is a rather difficult task. Radiocarbon dating of organic macrofossils is one tool, which can provide age control for the past $\sim 40 \mathrm{kyrs}$. Beyond that time, dating of lacustrine sediments requires other techniques with generally higher uncertainties. Positioned downwind of most of the Italian volcanoes active during the Quaternary, Lake Ohrid contains a sediment record that is an excellent archive of volcanic ash (Wagner et al., 2008a, b; Vogel et al., 2010b; Sulpizio et al., 2010). Since these tephra layers can be identified and, most importantly, correlated based on their chemical and morphological characteristics to eruptions with known ages, they serve as important stratigraphic and chronological markers. Other techniques such as luminescence and electron spin resonance (ESR) dating extend the datable range of the lake terrace levels.

The main objectives of this study are to describe and quantify lake level changes within ancient Lake Ohrid that have been identified in seismic data up to a penetration depth of 0.7 s Two Way Travel Time (TWT). We investigated patterns of lake level fluctuations by combining hydro-acoustic data with sedimentological and chronological data from lake sediment records. Specific objectives are: (i) to analyze whether lake level changes have occurred quickly, (ii) to date periods with constant lake levels in the past, (iii) to reconstruct ancient coastlines, (iv) to investigate the paleoenvironmental evolution of Ohrid Bay since the penultimate glacial period (MIS 6), and (v) to evaluate whether changes of the lake surface area and volume can be linked to changes in biodiversity within ancient Lake Ohrid.

\section{Setting}

Lake Ohrid $\left(41^{\circ} 01^{\prime} \mathrm{N}, 20^{\circ} 43^{\prime} \mathrm{E}\right.$; Fig. 1$)$ is located in a tectonically active graben system of the Western Macedonian geotectonic zone (Aliaj et al., 2001) at an altitude of $693 \mathrm{~m}$ 


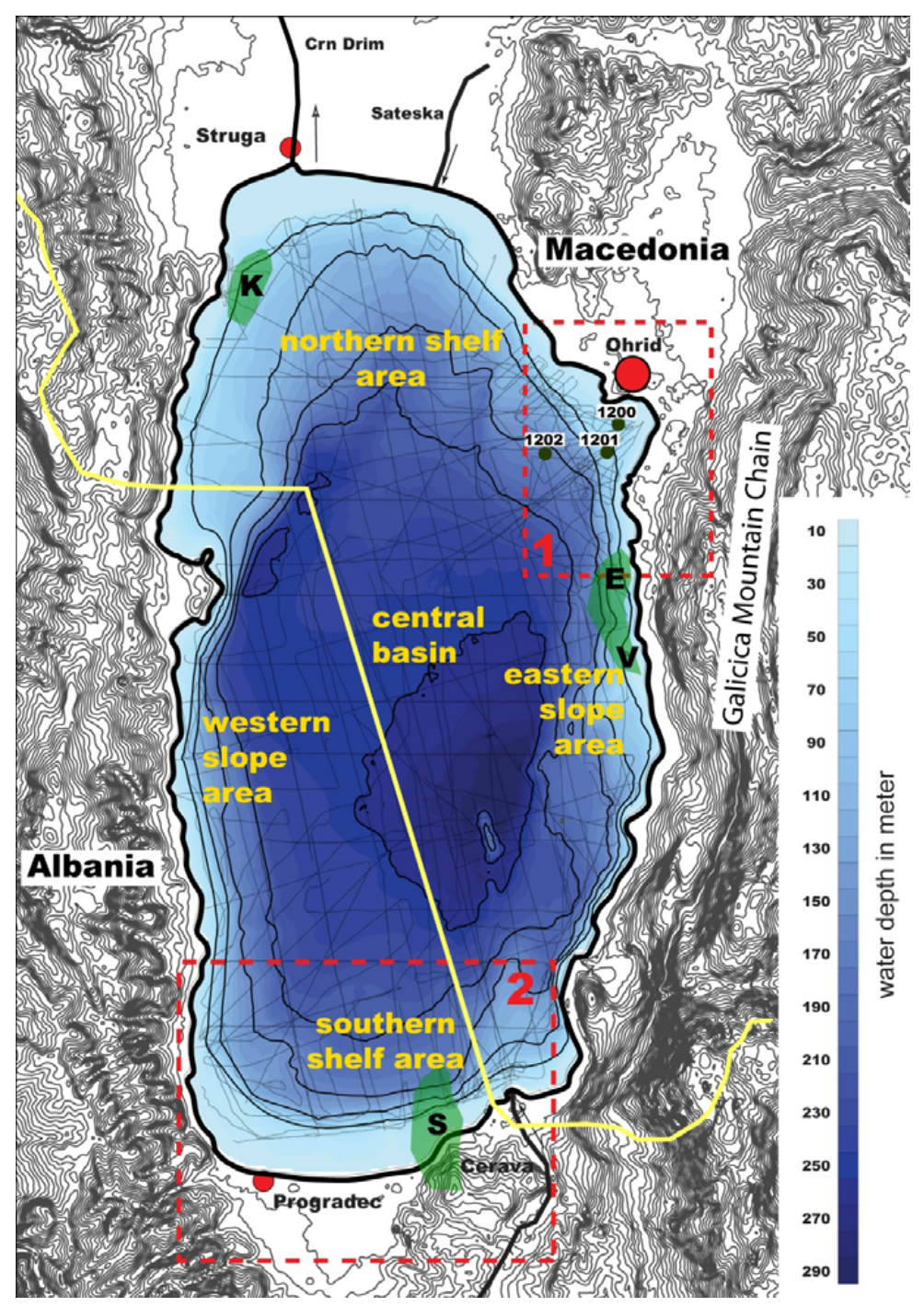

Fig. 2. Map showing bathymetry and topography of ancient Lake Ohrid and its surrounding area. The lake can be divided into six morphological sections: Ohrid Bay, southern and northern shelf area, western and eastern slope area, and central basin. Three rivers: Crn Drim, Sateska, and Cerava are marked with an arrow indicating the direction of flow. Red dashed line indicates two major study areas: 1: Ohrid Bay with core locations of Co1200-1202 as green spots, 2: southern Area. Yellow line is the boundary between Macedonia and Albania. Spring areas are marked in light green $(\mathrm{K}=$ Kalista, $\mathrm{E}=$ Elesec, $\mathrm{V}=$ Veli $\mathrm{Dab}$, and $\mathrm{S}=$ subaquatic and subsurface springs near the monastery Sveti Naum). Light gray lines mark seismic surveys since 2004.

above sea level (Fig. 1). The lake has a maximum length of ca. $30 \mathrm{~km}$, a maximum width of ca. $15 \mathrm{~km}$, and covers an area of ca. $360 \mathrm{~km}^{2}$ (Stankovic, 1960, Fig. 2). The morphology of the Lake Ohrid basin is relatively simple with a deep flat central basin, steep margins along major boundary faults at its eastern and western terminations, and shallow shelf areas in the northern and southern region (Wagner et al., 2008a, Fig. 2). The average water depth of the lake is ca. $150 \mathrm{~m}$ with a maximum water depth of $290 \mathrm{~m}$ and a total volume of $50.7 \mathrm{~km}^{3}$ (Popovska and Bonacci, 2007, Fig. 2).

Karst aquifers, charged from precipitation in the surrounding mountain ranges and from its sister Lake Prespa, enter
Lake Ohrid as sub-aquatic springs ( $\sim 49 \%$ ) in water depth up to $150 \mathrm{~m}$ (Matzinger et al., 2006; Albrecht and Wilke, 2008; Matter et al., 2010,) and as surface springs (51\%, Fig. 2, Albrecht and Wilke, 2008). Four main areas of sub-aquatic springs have been described so far: Kalista, Elesec, Veli Dab, and Sveti Naum (Albrecht and Wilke, 2008; Matter et al., 2010, Fig. 2). Surface springs can be found within the spring lake at Sveti Naum Monastry and sister spring complex Zagorican/Tushemist as well as some minor springs in the northern area of Lake Ohrid (Popovska and Bonacchi, 2007; Albrecht and Wilke, 2008, Fig. 2). In addition to karstic inflows, water enters Lake Ohrid by rivers and 


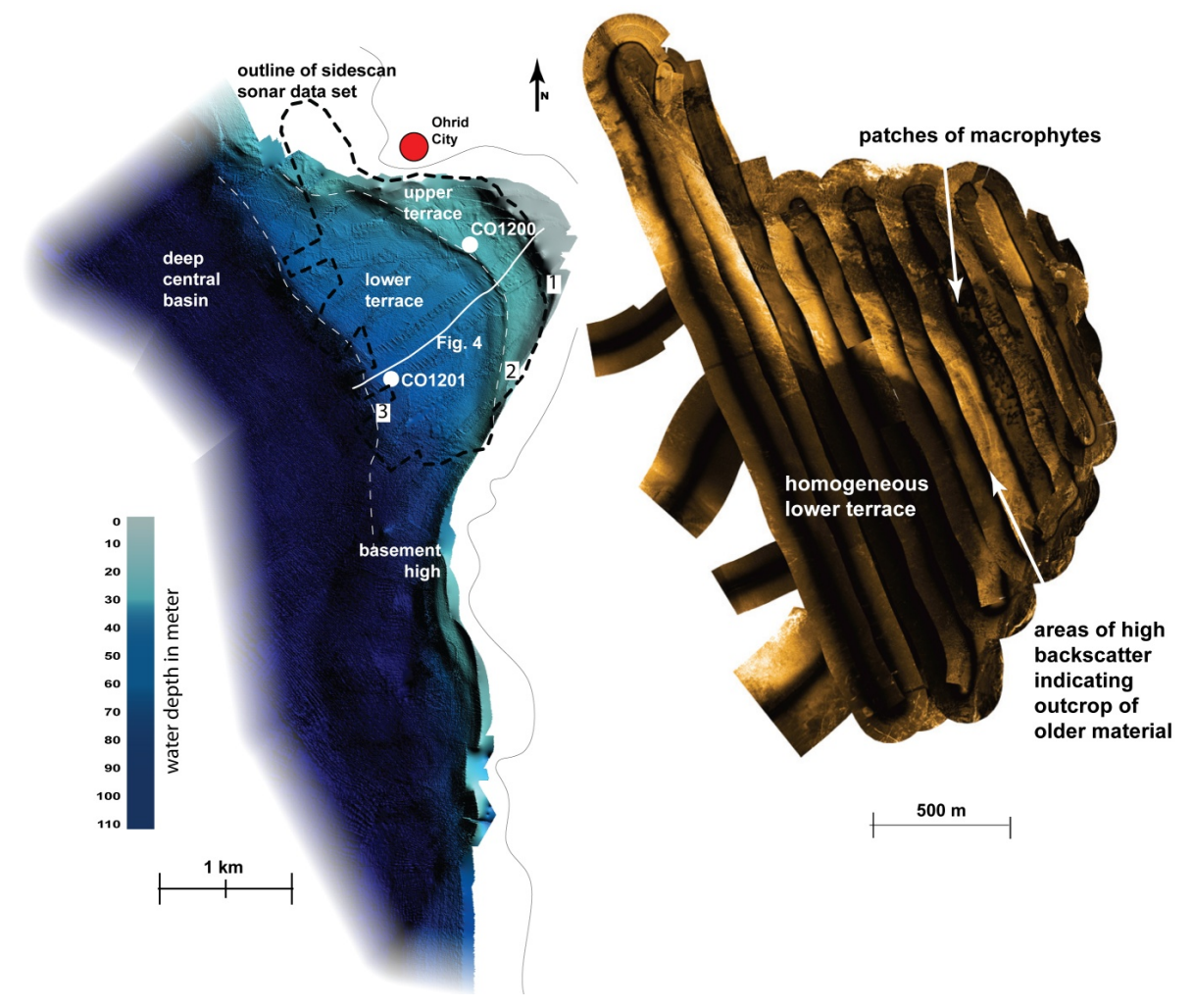

Fig. 3. Bathymetric map of Ohrid Bay (left) with major morphological features such as upper and lower terrace, deep central basin, three morphological steps (1, 2, 3 at water depth $15 \mathrm{~m}, 35 \mathrm{~m}$, and $60 \mathrm{~m}$, respectively). Locations of sediment cores (Co1200, Co1201) are marked as white dots. Sidescan sonar mosaic (right) images the upper portion of Ohrid Bay. Bright colors are areas of high backscatter. The outline of the sidescan sonar mosaic is shown as dashed line on the bathymetry. Note the different scales for each map. See Fig. 2 for location.

direct precipitation (Matzinger et al., 2006). At present, the Sateska and Cerava Rivers are the main riverine inflows to Lake Ohrid. Water leaves Lake Ohrid through the River Crn Drim ( $\sim 60 \%)$ and by evaporation ( $\sim 40 \%$, Matzinger et al., 2006, Fig. 2). No significant riverine inlets are found in close proximity to Ohrid Bay.

\section{Methods}

\subsection{Hydro-acoustics}

The first hydro-acoustic data were acquired in spring 2004 by means of a parametric sediment echosounder (Wagner et al., 2008a). In September 2007 and June 2008 we carried out two multichannel seismic surveys using a small airgun $(0.251$ and $0.1 \mathrm{l})$ and a $100 \mathrm{~m}$-long 16-channel streamer. The processing procedure included trace editing, set-up geometry, static corrections, velocity analysis, normal move-out corrections, band-pass frequency filtering (frequency content: 35/60$600 / 900 \mathrm{~Hz}$ ), stack, and time migration. We applied a common midpoint spacing of $5 \mathrm{~m}$ throughout. During both multichannel surveys a parametric sediment echosounder with a main frequency of $10 \mathrm{kHz}$ was operated simultaneously.
Stacking of two adjacent pings improved the signal-to-noise ratio. We calculated water depth and penetration from the echosounder using a constant velocity of $1470 \mathrm{~ms}^{-1}$. A dense net of sediment echosounder lines with a spacing of less than $500 \mathrm{~m}$ (in Ohrid Bay even less than $100 \mathrm{~m}$ ) is now available for Lake Ohrid (Fig. 2).

Sidescan sonar data were acquired in 2008 using a Klein 3000 dual frequency sonar with $100 \mathrm{kHz}$ and $500 \mathrm{kHz}$. The Ohrid Bay area was mapped between 3 and about $100 \mathrm{~m}$ water depth. The sonar was usually adjusted to cover $75-100 \mathrm{~m}$ on either side with individual profiles spaced $75-100 \mathrm{~m}$ apart. In this way, complete coverage of the working area was achieved.

In September/October 2009, we collected high-resolution bathymetric data by means of ELAC Seabeam 1180 system. The system uses 126 beams with a total opening angle of $153^{\circ}$ and operates with a frequency of $180 \mathrm{kHz}$. The transducers were mounted at the bow of the vessel. Vessel motion was measured using an OCTANS IV motion sensor that provides roll, pitch, and heave correction. We collected sound velocity profiles at different locations across Lake Ohrid. Processing of the data was mainly done by means of the software package MBSystem (Caress and Chayes, 2005) and 
Table 1. Radiocarbon ages and calendar ages inferred using CalPal-2007online (Danzeglocke et al., 2008) of plant macrofossils from cores Co1200 and Co1201.

\begin{tabular}{lllll}
\hline Sample ID & Core ID & Depth $(\mathrm{cm})$ & ${ }^{14} \mathrm{C}$ age $(\mathrm{yrs}$ BP) & Calendar age (cal yrs BP) \\
\hline KIA37138 & Co1200 & 6 & 1954 AD & 1954 AD \\
KIA37139 & Co1200 & 13 & $21610 \pm 185$ & $25815 \pm 522$ \\
KIA37140 & Co1201 & 15 & $5010 \pm 35$ & $5773 \pm 82$ \\
KIA37141 & Co1201 & 18 & $15810 \pm 155$ & $19030 \pm 244$ \\
\hline
\end{tabular}

Table 2. Dating results and radioactivity data. Ages from core Co1201 were derived by IRSL dating, sample K-5764 from core Co1200 was $\mathrm{ESR}^{1}$ dated.

\begin{tabular}{|c|c|c|c|c|c|c|c|c|c|c|}
\hline $\begin{array}{l}\text { Lab. } \\
\text { Code }\end{array}$ & Sample ID & $\begin{array}{l}\text { Water content } \\
(\text { weight- } \%)^{2}\end{array}$ & $\begin{array}{l}\text { Burial } \\
\text { depth } \\
\text { (m) }\end{array}$ & $\mathrm{U}(\mathrm{ppm})^{3}$ & Th (ppm) & $\mathrm{K}(\%)$ & $\begin{array}{l}\text { De } \\
(\mathrm{Gy})\end{array}$ & $\begin{array}{l}\mathrm{D}_{0} \\
(\mathrm{~Gy} \\
\left.\mathrm{ka}^{-1}\right)\end{array}$ & $\begin{array}{l}\text { Age } \\
\text { (ka) }\end{array}$ & $\begin{array}{l}\text { IRSL-Age } \\
\text { Fading cor- } \\
\text { rected } \\
\text { (ka) }\end{array}$ \\
\hline C-L2573 & $\begin{array}{l}\text { Co1201-5 I } \\
(340-377 \mathrm{~cm})\end{array}$ & $30.3 \pm 4.5$ & 17.75 & $4.11 \pm 0.14$ & $15.75 \pm 0.72$ & $2.45 \pm 0.05$ & $479.6 \pm 33.0$ & $4.0 \pm 0.2$ & $119 \pm 10$ & $157 \pm 21$ \\
\hline C-L2574 & $\begin{array}{l}\text { Co1201-5 I } \\
(377-408 \mathrm{~cm})\end{array}$ & $29.9 \pm 4.5$ & 17.95 & $4.19 \pm 0.14$ & $16.00 \pm 0.74$ & $2.47 \pm 0.05$ & $558.0 \pm 31.8$ & $4.1 \pm 0.3$ & $137 \pm 127$ & $181 \pm 24$ \\
\hline C-L2575 & $\begin{array}{l}\text { Co1201-5 III } \\
(503-550 \mathrm{~cm})\end{array}$ & $29.2 \pm 4.4$ & 19.50 & $3.76 \pm 0.13$ & $14.86 \pm 0.68$ & $2.45 \pm 0.05$ & $372.3 \pm 24.6$ & $4.0 \pm 0.2$ & $93.4 \pm 8.1$ & $123 \pm 16$ \\
\hline C-L2576 & $\begin{array}{l}\text { Co1201-5 III } \\
(550-597 \mathrm{~cm})\end{array}$ & $30.9 \pm 4.6$ & 20.00 & $4.04 \pm 0.14$ & $15.67 \pm 0.72$ & $2.50 \pm 0.05$ & $438.1 \pm 40.2$ & $4.0 \pm 0.3$ & $109 \pm 12$ & $143 \pm 21$ \\
\hline K-5764 & $\begin{array}{l}\text { Co1200-6 III } \\
(230-262 \mathrm{~cm})\end{array}$ & $35-50$ & & $0.41 \pm 0.04$ & $0.33 \pm 0.03$ & $0.06 \pm 0.01$ & $16.40 \pm 1.23$ & & $130 \pm 28$ & \\
\hline
\end{tabular}

${ }^{1}$ The dose rates and ESR-ages were calculated for different water contents and different thicknesses of an overlying sediment unit and water column, as the depositional history was complex. The age estimate is the average from the maximum and minimum ages resulting from dose rate modelling.

2 Water content is the in-situ water content with $15 \%$ uncertainty.

${ }^{3}$ Internal U-content: $0.07 \pm 0.01 \mathrm{ppm}$

GMT (Wessel and Smith, 1991). The area of Ohrid Bay is covered from $20 \mathrm{~m}$ water depth into the deep basin.

\subsection{Sediment cores}

Cores Co1200 and Co1201 were recovered in fall 2007 from the northeastern part of Lake Ohrid where hydro-acoustic surveys indicated two sub-aquatic terrace levels at 32 and $60 \mathrm{~m}$ water depth (Fig. 3). The surface sediments and deeper sediments were collected using a $0.6-\mathrm{m}$ gravity corer and a 3$\mathrm{m}$-long percussion piston corer, respectively (both UWITEC Co.). The overlapping 3-m long core segments were subdivided into 1-m-long segments in the field.

Prior to sub-sampling one core halve was used for highresolution X-ray fluorescence (XRF) scanning by means of an ITRAX core scanner (COX Ltd.), equipped with a Motube set to $30 \mathrm{kV}$ and $30 \mathrm{~mA}$ and a Si-drift chamber detector. Scanning was performed at $2.5 \mathrm{~mm}$ resolution and an analysis time of $20 \mathrm{~s}$ per measurement. The obtained count rates for $\mathrm{Ti}, \mathrm{K}$, and $\mathrm{Ca}$ can be used as estimates of the relative concentrations for these elements (Croudace et al., 2006).

Sub-sampling was performed at $2 \mathrm{~cm}$ intervals. The water content (WC) for each sample was determined from the weight difference between wet and freeze-dried samples. Aliquots of the freeze-dried subsamples were ground to a particle size below $63 \mu \mathrm{m}$ using a planetary mill for subsequent biogeochemical analyses, which was done at $6 \mathrm{~cm}$ resolution. Total carbon (TC) concentrations, were measured with a Vario Micro Cube combustion CNS elemental analyzer (VARIO Co.). Samples for total organic carbon (TOC) analysis were pre-treated with $\mathrm{HCl}(10 \%)$ at a temperature of $80^{\circ} \mathrm{C}$ to remove carbonates and then analyzed using a Leco CS-225 carbon-sulfur detector (LECO Corp.). The amount of total inorganic carbon (TIC) was determined from the difference between TC and TOC. The calcite $\left(\mathrm{CaCO}_{3}\right)$ content was calculated from TIC under the assumption that TIC solely originates from $\mathrm{CaCO}_{3}$.

In order to develop a chronological framework for cores Co1200 and Co1201 radiocarbon, infrared stimulated luminescence (IRSL), electron spin resonance (ESR) dating, and tephrostratigraphy was applied. For radiocarbon dating plant macrofossils from 6 and $13 \mathrm{~cm}$ depth in core Co1200 and from 15 and $18 \mathrm{~cm}$ depth in core Co1201 were used (Table 1). Radiocarbon dating was performed by accelerator mass spectrometry (AMS) at the Leibniz Laboratory for Radiometric Dating and Isotope Research in Kiel, Germany. The obtained ages were calibrated into calendar years before 
Table 3. Relationship between morphological, seismic (multichannel and sediment echosounder) and lithological data of Ohrid Bay. LGM = Last Glacial Maximum, MIS = Marine Isostage.

\begin{tabular}{|c|c|c|c|c|c|c|c|c|}
\hline Morphology & \multicolumn{2}{|c|}{ stratigraphy } & \multirow[t]{2}{*}{ cores } & \multirow{2}{*}{$\begin{array}{l}\text { system } \\
\text { tracts }\end{array}$} & \multirow[t]{2}{*}{ age } & \multirow{2}{*}{$\begin{array}{l}\text { lake } \\
\text { level }\end{array}$} & \multirow{2}{*}{$\begin{array}{l}\text { base } \\
\text { level }\end{array}$} & \multirow{2}{*}{$\begin{array}{l}\text { shoreline } \\
\text { trajectory }\end{array}$} \\
\hline step 1 & $\begin{array}{l}\text { seismic } \\
\text { units }\end{array}$ & $\begin{array}{l}\text { Litho- } \\
\text { facies }\end{array}$ & & & & & & \\
\hline $\begin{array}{l}\text { upper } \\
\text { terrace }\end{array}$ & $\begin{array}{l}\mathrm{H} \\
\mathrm{G} \\
\mathrm{F}\end{array}$ & $\begin{array}{c}\text { I } \\
\text { II } \\
\text { III }\end{array}$ & $\begin{array}{l}\text { Co1200 } \\
\text { Co1200 } \\
\text { Co1200 }\end{array}$ & $\begin{array}{c}\text { HST } 9 \\
\text { HST } 9 \\
\text { FRST } 8\end{array}$ & $\begin{array}{l}\text { Holocene } \\
\text { LGM } \\
\text { MIS } 5\end{array}$ & $\begin{array}{l}\text { modern } \\
\text { modern } \\
\text { stage } 3\end{array}$ & $\sim 35 \mathrm{~m}$ & $\begin{array}{c}\text { transgression } \\
\text { transgression } \\
\text { minor } \\
\text { regression }\end{array}$ \\
\hline step 2 & $\begin{array}{c}\text { outcrop } \\
\text { F }\end{array}$ & III & Co1200 & FRST 8 & MIS 5 & stage 3 & $\sim 35 \mathrm{~m}$ & $\begin{array}{l}\text { minor } \\
\text { regression }\end{array}$ \\
\hline $\begin{array}{l}\text { lower } \\
\text { terrace }\end{array}$ & $\begin{array}{c}\mathrm{H} \\
\mathrm{G} \\
\mathrm{E}_{2} \\
\mathrm{E}_{1}\end{array}$ & $\begin{array}{c}\text { I } \\
\text { II } \\
- \\
\text { IV }\end{array}$ & $\begin{array}{c}\text { Co1201 } \\
\text { Co1201 } \\
- \\
\text { Co1201 }\end{array}$ & $\begin{array}{l}\text { HST } 9 \\
\text { HST } 9 \\
\text { HST } 7 \\
\text { FRST } 6\end{array}$ & $\begin{array}{c}\text { Holocene } \\
\text { LGM } \\
\text { late MIS 6/ MIS } 5 \\
\text { MIS } 6\end{array}$ & $\begin{array}{c}\text { modern } \\
\text { modern } \\
\text { stage } 2 \\
\text { stage } 1\end{array}$ & $\begin{array}{l}\sim 25 \mathrm{~m} \\
\sim 60 \mathrm{~m}\end{array}$ & $\begin{array}{c}\text { transgression } \\
\text { transgression } \\
\text { transgression } \\
\text { continuous } \\
\text { regression }\end{array}$ \\
\hline step 3 & $\begin{array}{c}\text { outcrop } \\
\text { E }\end{array}$ & IV & Co1201 & FRST 6 & MIS 6 & stage 1 & $\sim 60 \mathrm{~m}$ & $\begin{array}{l}\text { continuous } \\
\text { regression }\end{array}$ \\
\hline $\begin{array}{c}\text { deep central } \\
\text { basin }\end{array}$ & & & & & & & & \\
\hline
\end{tabular}

present (cal yrs BP) using CalPal-2007online and the CalPal2007_HULU calibration curve (Danzeglocke et al., 2008).

IRSL dating was solely performed on four samples from core Co1201. In the laboratory under subdued illumination about $20 \mathrm{~cm}^{3}$ material was taken from four different depths (340-377, 377-408, 503-550, and 550-597 cm, Table 2) using the core half, which was not XRF scanned. Additionally samples at each of the four depths were taken for dose rate measurements. The concentrations of $\mathrm{U}, \mathrm{Th}$ and $\mathrm{K}$ were determined by gamma-ray spectrometry using approximately $400 \mathrm{~g}$ of sediment per sample. Several dating attempts applied to quartz extracts like a standard optically stimulated luminescence single aliquot regeneration protocol or an isothermal TL approach failed due to saturation effects. Hence, IRSL measurements were carried out on potassiumrich feldspar extracts in the blue detection range $(410 \mathrm{~nm}$ interference filter) using a single aliquot regeneration protocol. Fading tests and fading corrections were applied to the IRSL ages as described by Auclair et al. (2003), Lamothe et al. (2003), and Preusser et al. (2008) for further details on luminescence dating and the problem of fading.

We performed ESR dating only on one horizon in core Co1200. For this purpose we collected large mollusk shell fragments from a horizon at 230-262 cm depth (Table 2). In order to determine the radionuclide contents of the surrounding sediment and of the mollusks themselves we applied inductively coupled plasma (ICP)-mass spectrometry. We carried out ESR measurements using an additive dose protocol for multiple aliquots (Schellmann et al., 2008). Results of IRSL and ESR dating are summarized in Table 2.

Both cores Co1200 and Co1201 contained peculiar horizons consisting almost entirely of volcanic glass shards (tephra). Tephra horizons in core Co1200 occur at 38-40 and $85.5-120.5 \mathrm{~cm}$. Tephra horizons in core Co1201 occur at 110-126, 184-186, and 190-192. From these horizons we washed and sieved about $1 \mathrm{~cm}^{3}$. The $>40 \mu \mathrm{m}$ fraction was embedded in epoxy resin and screened for glass shards and micro-pumice fragments using scanning electron microscopy (SEM). We performed energy-dispersivespectrometry (EDS) analyses of glass shards and micropumice fragments using an EDAX-DX micro-analyzer mounted on a Philips SEM 515 (operating conditions: $20 \mathrm{kV}$ acceleration voltage, $100 \mathrm{~s}$ live time counting, $200-500 \mathrm{~nm}$ beam diameter, 2100-2400 shots per second, ZAF correction is a common matrix correction used in electron microprobe analysis. $\mathrm{Z}=$ atomic number, $\mathrm{A}=$ absorption, $\mathrm{F}=$ flourescence).

\subsection{Seismic stratigraphy and correlation with cores}

In total we defined 8 seismic units named from A (oldest unit overlying the basement) to $\mathrm{H}$ (most recent deposition only found in Ohrid Bay). Seismic sequences identified within the sediment echosounder profiles in Ohrid Bay could be directly assigned to lithofacies described in cores Co1200 and Co1201. A major fault at the southwestern end of Ohrid Bay 


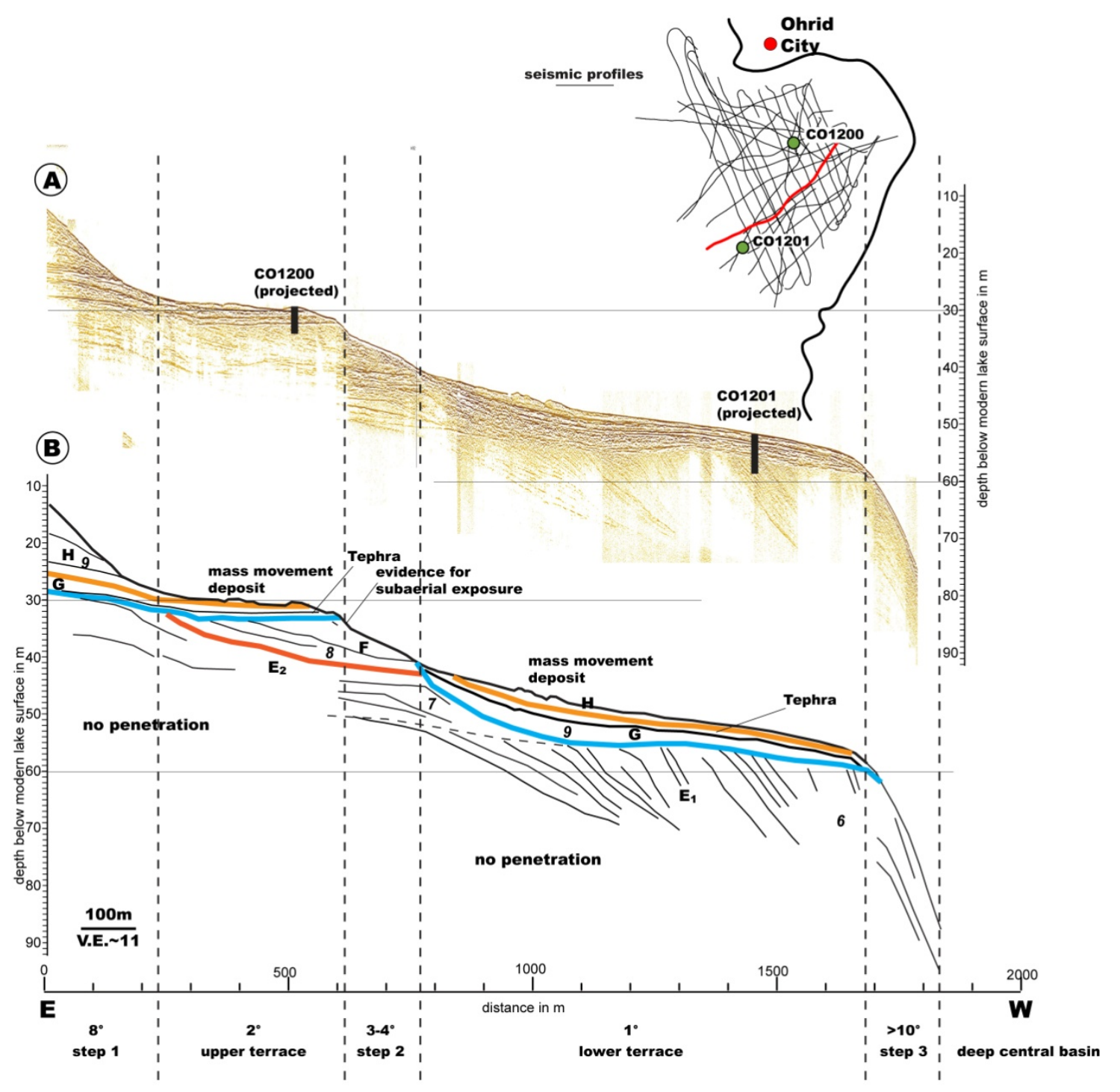

Fig. 4. East-west directed sediment echosounder line across Ohrid Bay over a distance of $2 \mathrm{~km}$ (see map inlet for location). (A) Uninterpreted section with projection of sediment cores (B) line drawing and interpretation of the section (colors indicating the base of each seismic unit are the same as colors used for Lithofacies in Figs. 5, 6). The profile shows the internal structure of the upper and lower terraces. Seismic units $\mathrm{E}_{1}, \mathrm{E}_{2} \mathrm{~F}, \mathrm{G}, \mathrm{H}$ and System tracts $6,7,8,9$, a tephra layer most likely assigned to (CI)/Y5 and areas with mass wasting deposits as evidenced by a hummocky topography are labeled. Slope angles are indicated at the bottom of the line drawing.

anticipated a direct tracing of prominent reflections within the sediment echosounder data in Ohrid Bay through the central basin into the southern area. For that reason we used additional lithological data available from Co1202 (Vogel et al., 2010a) below this fault in a water depth of $145 \mathrm{~m}$ comprising the same lithofacies as found in Co1200 and Co1201 of this study. This approach allowed correlating seismic signals observed in Ohrid Bay into the deeper part of the lake.

\section{Results}

\subsection{Ohrid Bay}

\subsubsection{Bathymetry and lake floor morphology}

High-resolution bathymetric data gathered offshore from the City of Ohrid show two gently dipping $\left(<1^{\circ}\right)$ plateaus (upper and lower terraces in Fig. 3) as well as three distinct morphological steps. The first morphological step drops down to a water depth of $30 \mathrm{~m}$. The upper terrace in $\sim 30 \mathrm{~m}$ water 


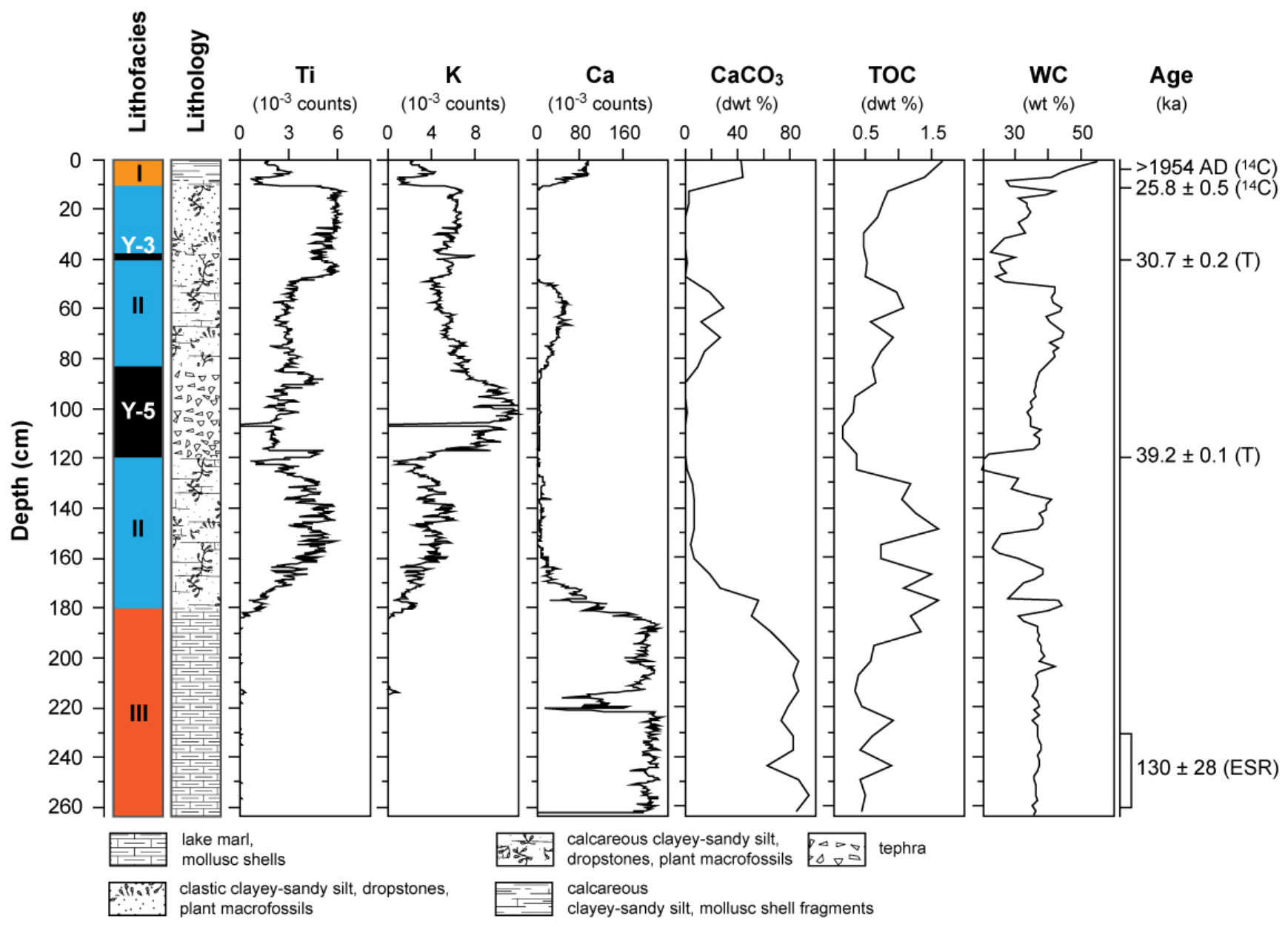

Fig. 5. Lithofacies, lithology, Ti-, $\mathrm{K}-$, $\mathrm{Ca}$ - intensities, $\mathrm{CaCO}_{3}$, total organic carbon (TOC) dry weight percentages, water content (WC), and age control points of core Co1200. ${ }^{14} \mathrm{C}=$ calibrated radiocarbon age, $\mathrm{T}=$ tephra age, ESR = electron spin resonance age. Location of core is shown on Figs. 3 and 4.

depth has an average width of $400 \mathrm{~m}$ (Figs. 3, 4). The outer edge of this upper terrace is characterized by a clear break in the slope gradient from $\sim 2^{\circ}$ to $\sim 4^{\circ}$ (step 2 on Fig. 4), which can be traced in a half circle parallel to the presentday northern coastline. At this break in slope the lake floor drops down to the up to $800 \mathrm{~m}$-wide lower terrace in $\sim 60 \mathrm{~m}$ water depth. Another prominent step in morphology (labeled 3 on Fig. 4) defines the outer edge of the lower terrace. At this step the lake floor drops to more than $200 \mathrm{~m}$ water depth with a slope angle of up to $10^{\circ}$ down into the central basin. A sub-lacustrine basement high that crops out in the southern part of the Ohrid Bay area is clearly visible in the bathymetric data (Fig. 3). The terminology used for each data set within Ohrid Bay is summarized in Table 3.

A side scan sonar mosaic images the surface texture of each individual terrace. High backscatter values along morphological steps mark exposures of terrace-building sediment sequences (Fig. 3). Small-scale patches of strong backscatter values on top of the upper terrace in a water depth of $30 \mathrm{~m}$ are indications of ancient eroded surfaces partly overlain by younger sediments. The distribution of macrophytes in littoral areas of Ohrid Bay is traceable by side scan sonar data.

\subsubsection{Stratigraphy}

The sediment echosounder dataset covers the entire Ohrid Bay showing the internal structure of the sediments up to a sub-surface depth of $50 \mathrm{~m}$ below the lake bottom. The grid of seismic lines is very dense (Fig. 4, map inlet). A set of parallel lines is running from north to south with a line spacing of less than $100 \mathrm{~m}$. In addition, numerous profiles were collected from the central lake basin perpendicular to the coastline across both terraces. The density of high-resolution seismic profiles allows us to correlate between the profiles.

Stratigraphic Unit E is divided into sub-units E1 and E2 (Fig. 4). Sub-unit E1 is characterized by oblique, parallel to sub-parallel reflections with increasing dip angles to the 


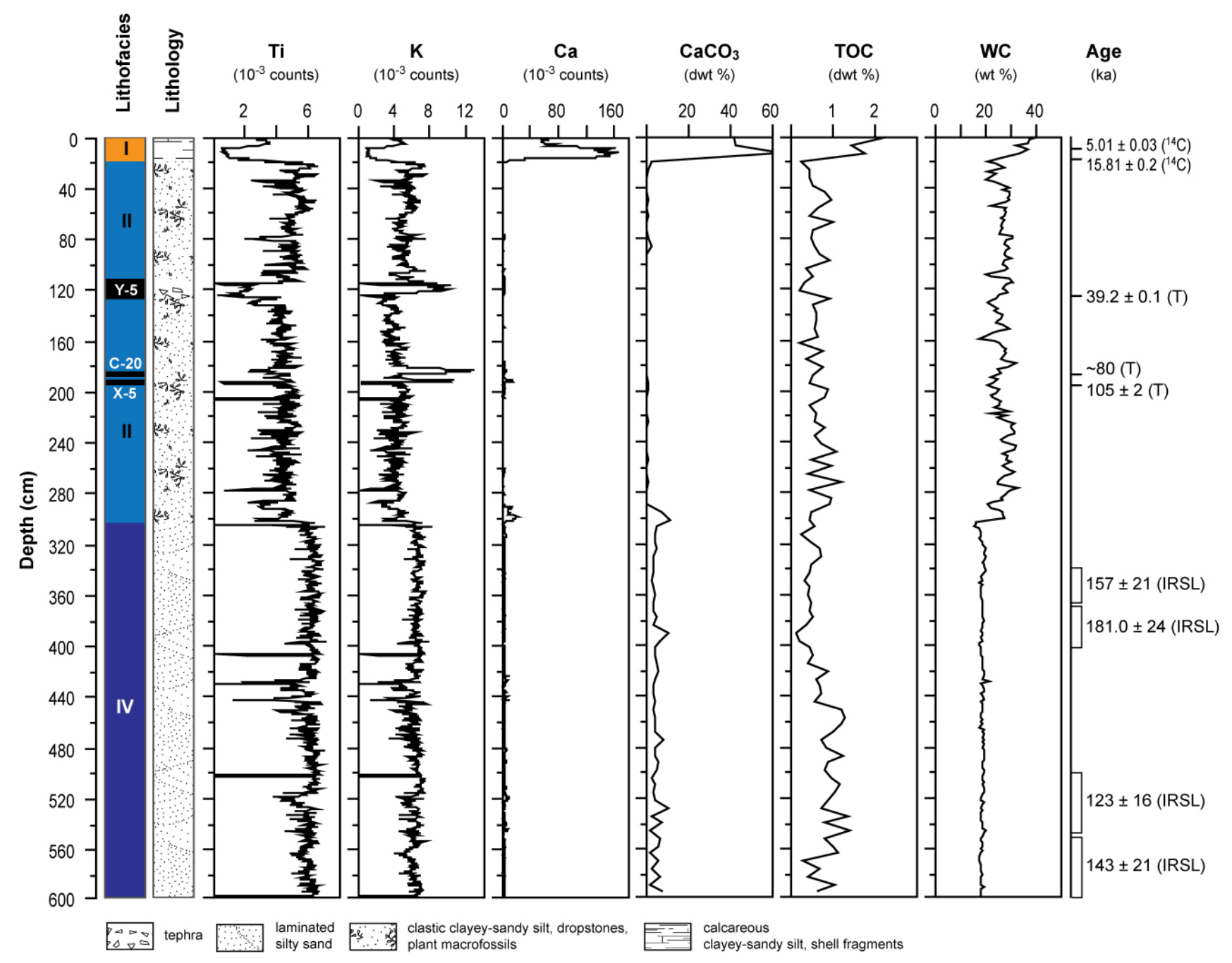

Fig. 6. Lithofacies, lithology, Ti-, $\mathrm{K}-$, $\mathrm{Ca}$ - intensities, $\mathrm{CaCO}_{3}$, total organic carbon (TOC) dry weight percentages, water content (WC), and age control points of core $\mathrm{Co} 1201 .{ }^{14} \mathrm{C}=$ calibrated radiocarbon age, $\mathrm{T}=$ tephra age, IRSL $=$ infrared stimulated luminescence age. Location of core is shown on Figs. 3 and 4.

west, and a toplap surface as upper boundary. Due to the limited penetration of the acoustic waves, the lower boundary of Sub-unit E1 cannot be detected. A steep slope with an angle of $15^{\circ}$ forms the transition to the profundal part of the lake. Sub-unit E2 forming a prograding clinoform with medium amplitude reflections (Fig. 4) is stacked on top of sub-unit E1.

Unit $\mathrm{F}$ appears in the seismic data as a low-amplitude wedge truncated by erosional surfaces on top and to the west. Penetration into Unit F is limited, therefore only a few internal reflections are visible that indicate slightly basinward dipping strata (Fig. 4). Towards the west, Unit F crops out and causes high backscatter visible in the sidescan data.

Sediment depositions assigned to units $\mathrm{G}$ and $\mathrm{H}$ are found on both terraces. In a water depth of about $50 \mathrm{~m}$ (lower terrace) Unit $G$ onlaps onto Unit $F$ suggesting a transgressive sequence boundary (Fig. 4). A thinning of strata towards the west is observed. In close proximity to the lakeshore at water depths of about $30 \mathrm{~m}$ (upper terrace), sediments of units $\mathrm{G}$ and $\mathrm{H}$ discordantly cover Unit F. A high amplitude horizon within Unit G can be assigned to Y-5 tephra (see below). The youngest seismic Unit $\mathrm{H}$ is recognized by slightly loweramplitude reflections. A hummocky topography on both terraces indicates deposits of mass wasting processes (Fig. 4).

The cores recovered from the terraces in Ohrid Bay measure $2.63 \mathrm{~m}$ (Co1200) and $5.97 \mathrm{~m}$ (Co1201) after correlation by lithological core descriptions and XRF data of individual core segments. Lithological characteristics, geochemical indicators, and chronological constrains imply a subdivision of the sedimentary successions of cores Co1200 and Co1201 into four distinctly different lithological facies (Figs. 5, 6). 


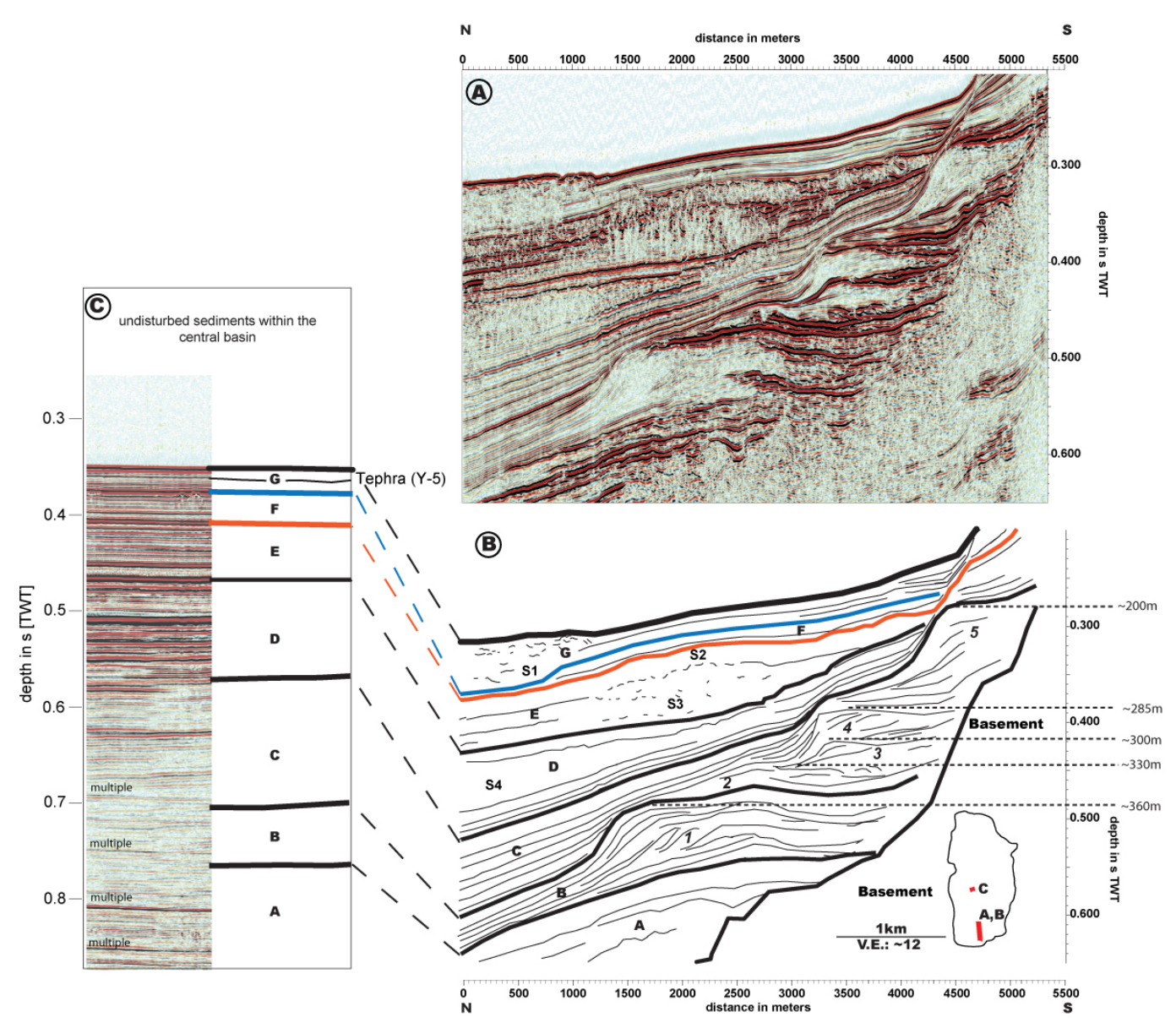

Fig. 7. Multichannel seismic cross section of sedimentary structures within the southern area running in a north-south direction over a distance of $5.5 \mathrm{~km}$. (A) uninterpreted and (B) interpreted section (colors indicating the base of each seismic unit are the same as colors used for Lithofacies in Fig. 5, 6). Interpretation of the seismic section shows that Lake Ohrid has a complex sedimentary evolution with a stepwise lake-level rise since its existence as water filled body as suggested by five major clinoform structures (1-5). Within younger sequences several mass wasting deposits were found indicating that sliding events are common in the southern area. A correlation of prominent reflections that bound major seismic units $(A-G)$ with well stratified sediments in the central basin of Lake Ohrid is shown in (C).

Lithofacies IV corresponding to seismic Unit E (see Table 3) forms the basal succession of core Co1201 between 305 and $597 \mathrm{~cm}$ depth and is limited at its top by a $0.5 \mathrm{~cm}$ thick sand layer with clear erosional base (Fig. 6). The sediments appear laminated with laminae width of $0.2-1 \mathrm{~cm}$, dark to light grey, and are mainly composed of clastic sandy silt. The dominance of clastic material in Lithofacies IV is well correlated to high $\mathrm{Ti}$ and $\mathrm{K}$ intensities. Terrestrial plant macrofossils and reworked mollusk shells are abundant in variable quantities explaining relatively high TOC concentrations and detectable amounts of $\mathrm{CaCO}_{3}$. Chronological control for Lithofacies IV sediments is given by IRSL dating of feldspar specimens sieved from the sand fraction of four horizons. IRSL dating on feldspars from the horizons at 340377 , 377-408, 503-550, and 550-597 $\mathrm{cm}$ yielded ages of
$157 \pm 21,181 \pm 24,123 \pm 16$, and $143 \pm 21 \mathrm{ka}$, respectively (Fig. 6, Table 2). These results can be regarded as minimum ages, since underestimation of the burial age for feldspar samples from deposits beyond $100 \mathrm{ka}$ notwithstanding correction procedures can be assumed (Wallinga et al., 2007). Dose rate measurements yielded very consistent nuclide concentrations (Table 2) for the four samples, suggesting a uniform sediment deposition. By contrast, the IRSL ages show no age increase with depth but an inconsistent array. This indicates partly insufficient bleaching before deposition or post-sedimentary influences and changes in the stratigraphic sequence after sedimentation. Variations in density, thickness of the overlying sediments or the water column do affect the dose rate calculations and might also contribute to the scatter of the ages. Taking all uncertainties into account, the 
IRSL dating results support a correlation of this stratigraphic unit with MIS 6.

Lithofacies III (corresponding to seismic Unit F, see Table 3) comprises the basal succession of core Co1200 between 181.5 and $263 \mathrm{~cm}$ (Fig. 5). A similar lithofacies is absent in core Co1201 (Fig. 6). Sediments assigned to Lithofacies III appear grayish-white and consist almost entirely of silt-sized endogenicic calcite $(\mathrm{CaCO} 3>70 \%)$, intact mollusk shells, and mollusk shell fragments. As indicated by extremely low $\mathrm{Ti}$ and $\mathrm{K}$ intensities clastic matter is almost absent. Low TOC $(<1.2 \%)$ concentrations originate from finely dispersed organic matter (OM) and few leave and shaft fragments of chara algae. ESR dating of mollusk shells collected in between 230 and $262 \mathrm{~cm}$ yielded a modeled age of $130 \pm 28 \mathrm{ka}$ (Table 2). This age, however, has a high uncertainty, because the post-depositional history regarding the thickness of the overlying sediment and water column has a high impact on the dose rate calculation for these deposits with very low radioactivity. A larger data set would be preferable to support this first age estimation. The transition from sediments of lithofacies III to II in core Co1200 is abrupt and occurs within a few centimeters. These transitional centimeters contain gravel, sand, and reworked mollusk shells without any grading.

Sediments deposited between 120.5-181.5 and 16$85.5 \mathrm{~cm}$ in core Co1200 (Fig. 5) and between 126-305 and $18.5-110 \mathrm{~cm}$ in core Co1201 (Fig. 6) are assigned to Lithofacies II (corresponding to seismic Unit G, see Table 3). Its sediments appear dark-gray and consist of clastic clayeysandy silts with frequent occurrences of gravel grains. Small reworked shell fragments occur in low abundance at both sites. $\mathrm{CaCO}_{3}$ concentrations are $<40 \%$ and TOC concentrations are $<2 \%$. Despite the general similarities for Lithofacies II sediments at both sites, some differences were also observed. For example, larger intact chara fragments are abundant in sediments of core Co1200, but only small leave and shaft pieces were found in core Co1201. Another difference is the amount of finely dispersed $\mathrm{OM}$ and $\mathrm{CaCO}_{3}$, which is higher in Lithofacies II of core Co1200 compared to Co1201.

A prominent and extensive tephra horizon can be seen by visual core inspection between $85.5-120.5 \mathrm{~cm}$ in core Co1200 and 110-126 cm in core Co1201. Geochemical and morphological correlation of glass shards from both tephra deposits point to the Campanian Ignimbrite $(\mathrm{CI}) / \mathrm{Y}-5$ eruption of the Campi Flegrei Caldera (Figs. 5, 6; Sulpizio et al., 2010), which is Ar/Ar dated to $39.2 \pm 0.1 \mathrm{ka}$ (De Vivo et al., 2001). Apart from this extensive tephra deposit additional tephra layers are found in both cores (Figs. 5, 6). A slightly younger tephra layer only identified in core Co1200 at 38$40 \mathrm{~cm}$ can be correlated to the Y-3 tephra layer (Campi Flegrei, Sulpizio et al., 2010), which is dated at $30.67 \pm 0.2 \mathrm{ka}$ (Sulpizio et al., 2003). Two additional tephra layers were recovered only in Co1201: One layer recognized at 184$186 \mathrm{~cm}$ that can be correlated to the C20 marine tephra (dated at 79-80 ka, Paterne et al., 1988). A second layer at 190-
$192 \mathrm{~cm}$ corresponds to the marine tephra X-5 (Sulpizio et al., 2010), which has an age of $105 \pm 2 \mathrm{ka}$ (Keller et al., 1978; Kraml, 1997).

The transition from Lithofacies II to Lithofacies I (corresponding to seismic Unit F, see Table 3) is characterized by a $2-3 \mathrm{~cm}$ thick sand layer between $13-16 \mathrm{~cm}$ (Co1200, Fig. 5) and 16.5-18.5 cm (Co1201, Fig. 6) with apparent erosive base in both cores. The sand layers show no upward fining in grain size, which would be typical for deposition from turbidity current, but is probably best explained as originating from some sort of mass movement process rather than lake level low stand. Radiocarbon dating of plant macrofossils just below the sand layer at $13 \mathrm{~cm}$ in core Co1200 and at $18 \mathrm{~cm}$ in core Co1201 yielded ages of $25815 \pm 522$ and $19030 \pm 244$ cal kyrs BP (Table 1), respectively, implying a hiatus in the cores after the Last Glacial Maximum (LGM).

Lithofacies I occurring in both cores $(0-13 \mathrm{~cm}$ in Co1200 and $0-16.5 \mathrm{~cm}$ in Co1201; Figs. 5, 6) as light-brown layer is composed of calcareous $\left(\mathrm{CaCO}_{3}>40 \%\right)$ clayey silt and contains complete bivalve shell and their fragments. TOC concentrations of up to $2 \%$ can be explained by finely dispersed $\mathrm{OM}$ as well as small leave and shaft parts from chara algae. Radiocarbon dating of plant macrofossils from Lithofacies I at $15 \mathrm{~cm}$ in core Co1201 yielded an age of $5773 \pm 82$ cal yrs BP (Table 1). The modern age of plant macrofossils from $6 \mathrm{~cm}$ in core Co1200 is probably a result of contamination with recent plant material.

\subsection{Southern area}

We observed several well-preserved prograding delta deposits within multichannel seismic data in the southern part of Lake Ohrid reflecting significant lake level changes in the past (Fig. 7). Stacked sigmoidally shaped clinoforms are recognized in the seismic cross section (Fig. 7). These clinoforms are characterized by low-amplitude bodies composed of topset, foreset, and bottomset reflections. Reflections within individual clinoform packages are marked in the interpreted seismic section (Fig. 7). Several high-amplitude reflections overly each wedge numbered as 1 to 5 from oldest to youngest.

Basinward of the clinoforms seven depositional sequences (A to $G$ ) were defined by tracing unconformities or their correlative conformities of reflections-bounding clinoform structures. The acoustic basement that limits penetration is recognized in the southern part of the profile rising up from the deeper central basin towards shallower shore areas. Unit $\mathrm{A}$, the oldest sequence overlying the basement is characterized by several high amplitude reflections. Units $\mathrm{B}$ and $\mathrm{C}$ have very similar seismic characteristics showing well-stratified, continuous reflections with medium amplitudes that onlap on foresets of clinoforms. Within each unit one or more prominent reflections are observed and marked in the interpreted section (Fig. 7). The next younger units, D and $\mathrm{E}$, display the most complex seismic architecture within 
this cross-section. Three major mass movements deposits (S2 to S4, Fig. 7), imaged as transparent units, are identified in units D and E. Prominent and continuous horizons occasionally mark the base of mass movement deposits and divide the unit in sub-units. Additional high-amplitude reflections within Unit E are well imaged. We speculate that the top of Unit $\mathrm{E}$ most likely marks the transition of the penultimate glacial period (MIS 6) to the last interglacial period (MIS 5) as the bounding reflection is of the same age as its counterpart in Ohrid Bay. Furthermore, units F and G correspond to the last interglacial period (MIS 5), and the last glacial period (MIS 4, 3, and 2), respectively. Although a direct correlation to cores in Ohrid Bay is not possible, prominent reflections of each individual unit (F and $\mathrm{G}$ ) can be traced to core Co1202 located within the bottomset of the lower terrace assigned to Lithofacies IV (Fig. 2, Vogel et al., 2010b) and therefore are reliably dated to the same age as their corresponding units identified in Ohrid Bay. Within well-stratified sediments of Unit $\mathrm{G}$, a prominent reflection most likely correlates to tephra layer Y-5 found in both cores described in this study (Figs. 47) as well as in Co1202 (Vogel et al., 2010a, b). Towards the north, one thick slide deposit characterized by a chaotic seismic facies is onlapping on well-stratified sediments of Unit G. Seismic stratigraphic units described above can be traced into the central basin characterized by thick undisturbed sediments (Fig. 7c).

\section{Discussion}

\subsection{Paleoenvironmental reconstructions}

Based on the data available, we reconstructed four main phases of lake level dynamics back to MIS 6 in Ohrid Bay. In a temporal context these phases can be described as follows: (1) the buildup of a lower terrace, $60 \mathrm{~m}$ below the present water table (Unit E1, Lithofacies IV) during the penultimate glacial period (MIS 6), (2) the development of the upper terrace (Unit F, Lithofacies III) during the last interglacial period (MIS 5), (3) sedimentation of Lithofacies II assigned to seismic Unit G during the last glacial period, and (4) midHolocene to modern sedimentation as evident by Lithofacies I referring to seismic Unit $\mathrm{H}$.

High amounts of coarse silt to sand-sized clastic material in Lithofacies IV in combination with the width of the lower terrace, implies sedimentation close to a river mouth over a significant time span. The seismic and sedimentological data suggest that the water-level of Lake Ohrid was up to $60 \mathrm{~m}$ lower than today, which could be due to significantly drier conditions. A drier climate at Lake Ohrid during MIS 6 correlates well with other reconstructions from northeastern Greece (Tzedakis et al., 2003) and the Levant region (Bar Matthews et al., 2003) and infers that most of the eastern Mediterranean was affected by these conditions. Since there is no significant inlet close to Ohrid Bay today, we assume that dewatering of the watershed during MIS 6 differed significantly in the past.

The only significant valley, which enters the Ohrid Bay, is a valley expanding from the northwestern slope of Galicica Mountains (Fig. 2). Today, this valley not drained by a significant river. However, higher discharge in the past, with a significant supply of clastic material forming the lower terrace, could have been due to abundance and advance of local glaciers, which are known to have reached mid-valley positions during MIS 6 in the region (Hughes et al., 2006). These glaciers might have supplied enough water and eroded material during spring-summer melt water pulses even though climate conditions were probably significantly drier than today.

The observed sediment characteristics of Lithofacies III deposited on the upper terrace (Table 3), in combination with chronological and stratigraphical constrains, point to deposition of the corresponding sediments in a shallow-water, low-energy regime during the last interglacial period. The identification of gently dipping foresets supports a deposition of sediments in a low-energy regime. However, at the same time the area was affected by wave-action resulting in a transport of material towards the edge of the subaquatic terrace. Input of coarse-grained clastic material by riverine inflows was negligible, thus implying the river draining the valley on the northeastern slope of Lake Ohrid was active during the last interglacial period (MIS 5). The high amount of bio-induced carbonate and the absence of clastic material within Lithofacies III indicate a warm climate and also support humid conditions favoring Mediterranean tree cover and related soil stability in the surrounding mountains as suggested by Lézine et al. (2010). Warm climate conditions during the last interglacial period are reported from other paleoclimate records within the Mediterranean region (Tzedakis et al., 2003; Martrat et al., 2004; Allen and Huntley, 2009; Vogel et al., 2010a).

Lithofacies II has been identified in both cores but with slight differences in composition indicating that time and depth of deposition slightly changed. In core Co1201 on the lower terrace the chara fragments were less abundant and less intact compared to the upper terrace pointing to a higher energy regime during deposition. Furthermore the finely dispersed $\mathrm{OM}$ and $\mathrm{CaCO}_{3}$ was less than in Lithofacies II of core Co1200. Our interpretation is that the water level at the beginning of the last glacial period (MIS 4, 3, and 2) was about $30 \mathrm{~m}$ or less so that sediment got deposited mostly on the lower terrace. Broken fragments within Lithofacies II of core Co1201 indicate a transport of material from the upper terrace before final deposition. At the end of the last glacial period the water level must have rose and finally covered also the upper terrace. Another indication for a lake level rise within the last glacial period is the difference in thickness and age between the cores within the same Lithofacies. In core Co1201 (lower terrace) Lithofacies II is $120 \mathrm{~cm}$ thicker 


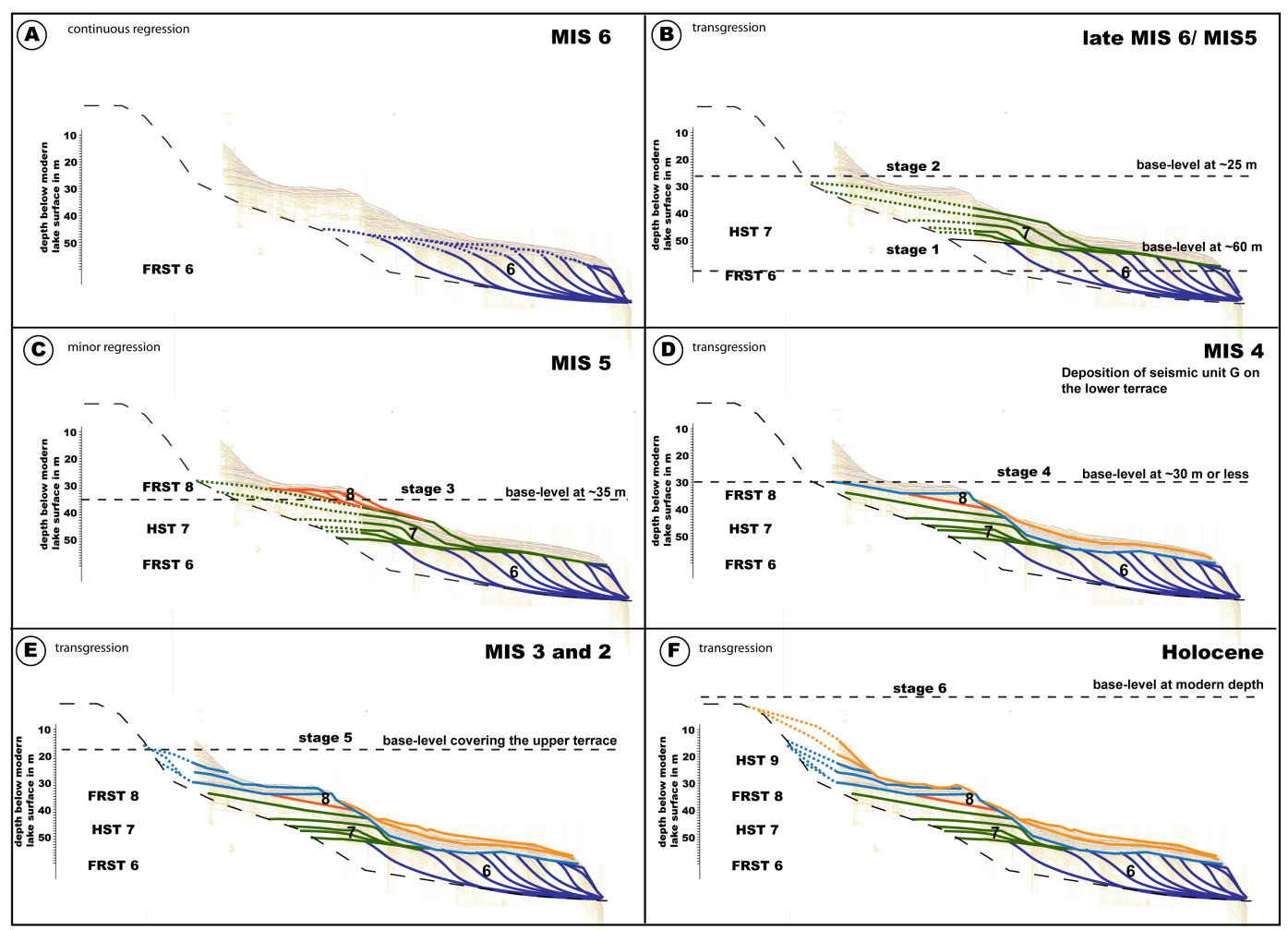

Fig. 8. The conceptual model illustrates the sedimentary evolution of terraces in Ohrid Bay since MIS 6 (penultimate glacial period). (FRST = Forced Regression System Tract, HST = Highstand System Tract, MIS = Marine Isotope Stage). As the significantly older clinoforms within the southern area are labeled 1-5, the numbering in this model for Ohrid bay starts with FRST 6. After a continuous regression during MIS 6 with subsequent formation of FRST 6 (A) the lake level rose to about $35 \mathrm{~m}$ as indicated by HST 7 (B). This period is followed by a falling lake level evidenced by FRST 8 (C). After a lowstand with an exposure of the upper terrace and subsequent erosion of HST 7 and FRST 8 the lake level rose in two steps during MIS 4, 3, and 2. After the first rise, only the lower terrace was covered by lake water (D) following the second lake level rise, also the upper terrace was then covered by water and sediments were deposited on both terraces (E). Finally, deposition of sediments assigned to lithofacies II and I took place (F) at modern water depth.

compared to core Co1200 and comprises two additional ash layers (C-20, X-5) that could be dated to $80 \mathrm{ka}$ and $105 \mathrm{ka}$. Only the CI/Y-5-tephra dated to $39 \mathrm{ka}$ was identified in both cores.

The most recent sediments comprising Lithofacies I in cores Co1200 and Co1201 represent a deposition of midHolocene to modern-day sediments at both sites. Since larger intact chara fragments and coarser clasts are absent throughout Lithofacies I we conclude that both sites remained well below the chara belt $(>30 \mathrm{~m})$ throughout the period of deposition. The hemipelagic characteristics of units $\mathrm{G}$ and $\mathrm{H}$ suggest environmental conditions comparable to those of today.

By now we have shown that our data can be used to reconstruct paleoenvironmental conditions in Lake Ohrid since the penultimate glacial period though the effect of subsidence was neglected. Lake Ohrid is a tectonic active basin that experienced subsidence since its formation although exact subsidence rates are unknown. Ohrid Bay is one area within the lake that only subsided slightly at least during the time span we investigated in this study because it is comparable to a hinged margin setting or a relay ramp (linkage between two segments between overlapping faults, Gawthorpe and Leeder, 2000) within the eastern major boundary fault complex. These settings are well known to experience the lowest subsidence rates within a fault complex. Hence subsidence is assumed to be small. In addition we do not observe active faults on our sediment echosounder profiles of Ohrid Bay and therefore no indication for active local tectonics. Subsidence caused by sediment load due to the load itself and compaction processes is also expected to be low because significant effects are only reported for larger time spans and higher dimensional margins (Sclater et al., 1980; Reynolds et al., 1991; Moore et al., 1997).

Our detailed survey by means of echosounder profiling and bathymetric mapping of almost the entire lake floor revealed that Ohrid Bay is the only area suitable for investigating lake level fluctuations. One would assume that such deltaic structure as observed offshore the City of Ohrid could also be found in the northern shore area and/or offshore Sveti 
Naum where the river Cerava enters the lake. The latter area shows a huge delta structure but unfortunately it is altered by tectonic forces anticipating an interpretation in terms of lake level fluctuations. In addition, no core information is available for this part of the lake, which is essential to date prominent reflectors in sediment echosounder data. The northern area on the other hand is not suitable for two reasons. No river enters Lake Ohrid in that area hence there is a lack of depositional material. More importantly, this area has experienced several events of mass movement resulting in a downward transport of reworked material and hence the loss of stratigraphic information.

\subsection{Lake level fluctuations and biodiversity}

We interpreted four major shoreline trajectories inferred from system tracts since the penultimate glacial period as inferred from sediment echosounder data from Ohrid Bay, which were combined with lithological information (Fig. 8). These system tracts include: (i) a forced regression system tract (FRST 6), (ii) a Highstand system tract (HST 7), (iii) a minor FRST 8, and (iv) a transgressive system tract or HST 9. All numbers referring to lake levels are given in meters below the modern water table.

A base level for the formation of FRST 6 (Fig. 8a) cannot clearly be identified. However, ostracods found within cores taken on land in vicinity to Ohrid Bay suggest that the shoreline of the lake was further landwards than at present (Hoffmann et al., personal. commun.). Hence we conclude that the base level must have been higher than today. A maximum of regression at a base level of $60 \mathrm{~m}$ is evident by truncation of topsets of FRST 6 (stage 1, Fig. 8b). A relative wide lower terrace still evident within the modern morphology, further suggests that the process of sediment bypassing took place over a long period (Figs. 3, 4, 8).

HST 7, which is only detectable by sediment echosounder data (Figs. 4, 8) and stacked on top of FRST 6, probably formed after a subsequent transgression to a base level of about $25 \mathrm{~m}$ (stage 2, Fig. 8b). Since the sediment cores did not recover material from sub-unit $\mathrm{E}_{2}$, exact dating of this period was not possible. Based on the superposition of HST 7 on top of the truncated surface of FRST 6, we suggest that HST 7 occurred during late MIS 6 or early MIS 5 (Fig. 8b).

A minor drop within MIS 5 (stage 3, Fig. 8c) following the previous HST 7 period is evidenced by FRST 8 (Unit F and Lithofacies III). Since Unit F shows evidences for calm conditions during deposition and subsequent sub-aerial exposure we conclude that the base level fell below the upper terrace level to a depth of about $35 \mathrm{~m}$ (Fig. 8c).

At the beginning of the last glacial period MIS 4 (stage 4, Fig. 8d) accumulation of sediments only took place on the lower terrace as evident by a difference in thickness of Lithofacies II of core Co1201 (seismic unit G) on the lower terrace and core Co1200 on the upper terrace. We speculate that deposition of seismic unit $\mathrm{G}$ on the upper terrace started

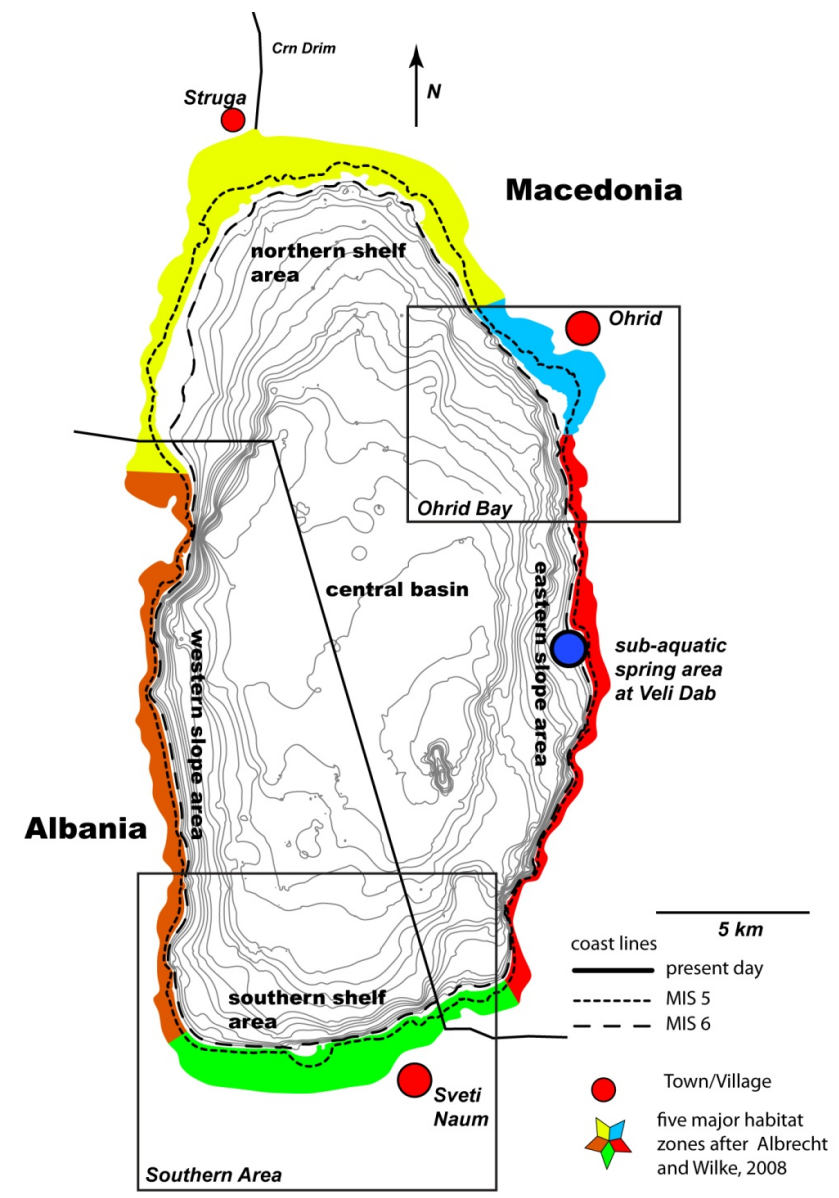

Fig. 9. Map of Lake Ohrid with major habitat zones (Albrecht and Wilke, 2008). Ancient coastlines as reconstructed in the study are shown as dashed lines. For details see text.

only $60 \mathrm{kyr}$ ago indicated by the absence of tephras C-20 and X-5 (stage 5, Fig. 8e).

Finally, seismic units $\mathrm{G}$ and $\mathrm{H}$ as well as lithofacies II and I point to a rapid lake level rise and subsequent stillstand after FRST 8, which led to depositional conditions of hemipelagic sediments that is still ongoing today (Fig. 8f).

The effect on the coastlines for the significant lake level fluctuations since the penultimate glacial period is illustrated in Fig. 9. Reconstruction of these ancient coastlines shows that only relatively small areas are affected by a $60 \mathrm{~m}$ drop in lake level. However, these areas are important for the endemism in Lake Ohrid (Albrecht and Wilke, 2008). For example, species have been identified as being endemic to the area around the sub-aquatic spring of Veli Dab (Fig. 9, Albrecht and Wilke, 2008). A minor drop in lake level probably results in a desiccation of this area and destruction of the habitat. On the other hand the initial drowning of that area can possibly be linked to the time where the punctuated endemism evolved. Although it is highly speculative it shows that lake level fluctuations can have an influence on 
the biodiversity within Lake Ohrid. Furthermore, Hauffe et al. (2010) observed that almost all gastropods live within a depth zone of 5-50 m. A minor drop in lake level may lead to a disconnection and/or isolation of certain areas from the proper lake resulting in allopatric speciation. Therefore we suggest that the evolution of endemic species is tentatively correlated with significant lake level fluctuations. Nevertheless this correlation remains speculative due to high uncertainties in speciation rate (Martens, 1997) and the timings of lake level stages or changes (Genner et al., 2010 and this study). Allopatric speciation involves a strict geographical barrier that prevents or reduces gene flow among subpopulations (for details see Albrecht and Wilke, 2008), and such a barrier apparently did not exist in ancient Lake Ohrid. The bathymetry of Lake Ohrid indicates that no subbasins or sub-aerial islands existed during MIS 6, when the lake level was $60 \mathrm{~m}$ lower than present day (Fig. 8). In comparison to the African Lake Malawi, where a magnitude of lake level changes greater than $550 \mathrm{~m}$ and subsequent expansion and establishment of rock fish populations was reconstructed (Genner et al., 2010), the magnitude of lake level change for Lake Ohrid since MIS 6 was probably too small for a major effect on speciation. One explanation is that the inferred lake level changes at Lake Ohrid had only a minor impact on the environment, particularly at the eastern shore, where rocky cliffs continue into deeper waters and an adaptation of species to a new living environment was not necessary. A change from calm conditions during lake level highstands to more dynamic conditions within the littoral zone after a drop in lake level may have an effect on species, which have been evolved during calm conditions as explained by Martens (1997). Within Lake Ohrid this is valid for small areas bounded by cliffs along the eastern shore line and more importantly within Ohrid Bay. These areas, although they were not completely desiccated, experienced a significant change in water depth with subsequent change in dynamic conditions.

Significant changes could have also affected the northern shore area where the bathymetry indicates a gently dipping sandy lake floor (Fig. 9). Here, even a minor transgression/regression of the shoreline would lead to drastic changes of subsurface properties and, subsequently, may have a major impact on the living environment.

In a longer term perspective, the endemism in the lake could have been affected by gradual lake level rise, since Lake Ohrid became established as water filled body. This lake level rise can be deduced from the five clinoform structures seen in the multichannel seismic data (Fig. 7) at the southern part of Lake Ohrid. Ancient depths of lake levels can be estimated by picking topset reflections. Using an average sound velocity of $1600 \mathrm{~ms}^{-1}$ for sediments, distinct reflections occur at 200,285,300,330, and $360 \mathrm{~m}$ depth below the modern lake level. We cannot assume that these numbers directly correspond to ancient lake levels because the subsidence history of the basin is not well known and current depths of the clinoforms are a combined effect of tectonic movements and lake level fluctuations. Nevertheless, pronounced clinoforms indicate significantly lower lake levels in the past with subsequent sudden changes in lake level.

A first attempt of dating individual clinoforms in the southern part of lake Ohrid was done by tracing reflections directly above or below the clinoforms to areas of undisturbed sediments within the central lake basin and assuming constant sedimentation rates. For example, the reflection interpreted to mark the transition of MIS 6 to MIS 5 can be traced all over Lake Ohrid. By using this reflection as a marker horizon an average sedimentation rate of $0.28 \mathrm{~mm} / \mathrm{yr}$ for the period younger than $130 \mathrm{ka}$. can be calculated for the deep basin. This sedimentation rate would provide an age of $\sim 41 \mathrm{kyr}$ for the Y-5 tephra, which is close to its real age. Extrapolation of this sedimentation rate leads to age estimations of $\sim 510 \mathrm{kyr}$, $\sim 600 \mathrm{kyr}, \sim 800 \mathrm{kyr}, \sim 940 \mathrm{kyr}$, and $\sim 1.1 \mathrm{Myr}$ for the base of Unit E, D, C, B, and the basement (or base of Unit A), respectively. However, these numbers are only first estimates and inhibit great uncertainties due to a lack of lithological information of sediments older than $130 \mathrm{ka}$. For example, our age estimate for the basement is much lower than ages suggested by other authors (Aliaj et al., 2001; Spirkovski et al., 2001; Dumurdzanov et al., 2005; Susnik et al., 2006) though the actual age of Lake Ohrid is still highly debated. The calculated ages can probably regarded as minimum values as velocities for sediments increase with depth and our model does not include possible hiatuses that would lead to older ages for the basement of Lake Ohrid. Seismic stratigraphy, however, shows that clinoforms offshore Sveti Naum are significantly older than MIS 6 (Fig. 7). Final interpretation can only be achieved by combining seismic data with the information from a deep drilling campaign, which will provide crucial information for reconstructing the subsidence history of the basin and a profound age model for the older sediments.

\section{Conclusions}

Our study illustrates that a combined geophysical and sedimentological approach is a powerful tool to investigate lake level fluctuations and link them to biodiversity in ancient lakes. Hydro-acoustic data show that Lake Ohrid has undergone significant lake level fluctuations. Multichannel seismic data penetrating into deeper parts of the sediments suggest that, in general, lake level rose stepwise since its establishment as water filled body. The topset reflections up to depths of $360 \mathrm{~m}$ below modern lake level as evident by pronounced clinoforms offshore Sveti Naum suggest that lake surface of Lake Ohrid was significantly reduced in former time periods. Further lithological data is needed to reduce uncertainties with respect to age estimates of prominent reflections as well as the subsidence history of the entire basin. An analysis of sediment echosounder profiles and core data 
within Ohrid Bay allows a more detailed reconstruction back to the penultimate glacial period. Two terraces are well preserved as morphological pattern within Ohrid Bay. The lower terrace (Unit E1, Lithofacies IV, FRST 6) is most likely a relic of a fan delta that formed in a high energy shallow water environment close to a river mouth during MIS 6. In contrast, the upper terrace (Unit F, Lithofacies III, FRST 8) formed in a low energy regime potentially under warm climate conditions with only minor rivers draining into Ohrid Bay during MIS 5. Four major shoreline trajectories can be deduced since the penultimate glacial period. A formation of sub-basins or sub-aerial parts since penultimate glacial is unlikely, since the lake level lowering by 30 or $60 \mathrm{~m}$ did not significantly affect the overall surface area of Lake Ohrid. However, the lake level changes may have had a significant impact on the speciation, since a great proportion of endemic species are found above $50 \mathrm{~m}$ water depth in modern Lake Ohrid.

Acknowledgements. We would like to thank our Macedonian colleagues G. Kostski, S. Trajanovski, and Z. Brdarovski from the Hydrobiological Institute Ohrid for their administrative and logistic support during numerous field campaigns to Lake Ohrid. Our undergraduate and graduate students are greatly acknowledged for their enthusiasm and help in the field and laboratory. We would like to thank workgroup of $\mathrm{H}$. Villinger for providing a Streamer system in 2008. Thanks to W. Weinrebe and N. Lindhorst for their technical support during the field campaign in 2009. We are grateful to S. Hall for valuable comments on earlier version of the manuscript. We received helpful reviews and short comments from M. Strasser of the MARUM in Bremen, Germany, C. Beck from Université de Savoie in France, and Jens Holtvoeth from University of Liverpool. This research was supported by DFG grants Kr2222/7, WA2109/1, We2210/3, and Da563/2.

Edited by: V. Brovkin

\section{References}

Albrecht, C. and Wilke, T.: Ancient Lake Ohrid: biodiversity and evolution, Hydrobiologia, 615, 103-140, 2008.

Aliaj, S., Baldassarre, G., and Shkupi, D.: Quaternary subsidence zones in Albania: some case studies, B. Eng. Geol. Environ., 59, 313-318, 2001.

Allen, J., Brandt, U., Brauer, A., Hubberten, H., Huntley, B., Keller, J., Kraml, M., Mackensen, A., Mingram, J., and Negendank, J.: Rapid environmental changes in southern Europe during the last glacial period, Nature, 400, 740-743, 1999.

Allen, J., Watts, W., McGee, E., and Huntley, B.: Holocene environmental variability - the record from Lago Grande di Monticchio, Italy, Quatern. Int., 88, 69-80, 2002.

Allen, J. and Huntley, B.: Last Interglacial palaeovegetation, palaeoenvironments and chronology: a new record from Lago Grande di Monticchio, southern Italy, Quaternary Sci. Rev., 28, 1521-1538, 2009.

Allen, P. A. and Allen, J. R.: Basin Analysis Principles and Applications, 2nd ed., Blackwell Publishing, 549 pp., 2005.
Anselmetti, F., Ariztegui, D., Hodell, D., Hillesheim, M., Brenner, M., Gilli, A., McKenzie, J., and Mueller, A.: Late Quaternary climate-induced lake level variations in Lake Petén Itzá, Guatemala, inferred from seismic stratigraphic analysis, Palaeogeogr. Palaeocl., 230, 52-69, 2006.

Anselmetti, F., Ariztegui, D., Batist, M., Gebhardt, A., Haberzettl, T., Niessen, F., Ohlendorf, C., and Zolitschka, B.: Environmental history of southern Patagonia unraveled by the seismic stratigraphy of Laguna Potrok Aike, Sedimentology, 873-892, doi:10.1111/j.1365-3091.2008.01002.x, 2009.

Auclair, M., Lamothe, M., and Huot, S.: Measurement of anomalous fading for feldspar IRSL using SAR, Radiat. Meas., 37, 487-492, 2003.

Bar-Matthews, M., Ayalon, A., Kaufman, A., and Wasserburg, G.: The Eastern Mediterranean paleoclimate as a reflection of regional events: Soreq cave, Israel, Earth Planet Sc. Lett., 166, 85-95, 1999.

Bar-Matthews, M., Ayalon, A., and Kaufman, A.: Timing and hydrological conditions of Sapropel events in the Eastern Mediterranean, as evident from speleothems, Soreq cave, Israel, Chem. Geol., 169, 145-156, 2000.

Bar-Matthews, M., Ayalon, A., Gilmour, M., Matthews, A., and Hawkesworth, C.: Sea-land oxygen isotopic relationships from planktonic foraminifera and speleothems in the Eastern Mediterranean region and their implication for paleorainfall during interglacial intervals, Geochimica et Cosmochimica Acta, 67, 31813199, 2003.

Bordon, A., Peyron, O., Lézine, A., Brewer, S., and Fouache, E.: Pollen-inferred Late-Glacial and Holocene climate in southern Balkans (Lake Maliq), Quatern. Int., 200, 19-30, 2009.

Caress, D. and Chayes, D.: MB-SYSTEM Release 5, www.ldgo. columbia.edu/MB-System, 2005.

Catuneanu, O., Abreu, V., Bhattacharya, J., Blum, M., Dalrymple, R., Eriksson, P., Fielding, C., Fisher, W., Galloway, W., and Gibling, M.: Towards the standardization of sequence stratigraphy, Earth Science Reviews, 92, 1-33, 2009.

Croudace, I., Rindby, A., and Rothwell, G.: ITRAX: description and evaluation of a new multi-function X-ray core scanner, New techniques in sediment core analysis, 267, 51-63, 2006.

D’Agostino, K., Seltzer, G., Baker, P., Fritz, S., and Dunbar, R.: Late-Quaternary lowstands of Lake Titicaca: evidence from high-resolution seismic data, Palaeogeogr. Palaeocl., 179, 97111, 2002.

Danzeglocke, U., Jöris, O., and Weninger, B.: CalPal-2007online, http://calpal_online.de/, 2008.

Daut, G., Mäusbacher, R., Baade, J., Gleixner, G., Kroemer, E., Mügler, I., Wallner, J., Wang, J., and Zhu, L.: Late Quaternary hydrological changes inferred from lake level fluctuations of Nam Co (Tibetan Plateau, China), Quatern. Int., 218, 86-93, doi:10.1016/j.quaint.2010.01.001, 2010.

De Vivo, B., Rolandi, G., Gans, P., Calvert, A., Bohrson, W., Spera, F., and Belkin, H.: New constraints on the pyroclastic eruptive history of the Campanian volcanic Plain (Italy), Miner. Petrol., 73, 47-65, 2001.

Drysdale, R., Zanchetta, G., Hellstrom, J., Fallick, A., and Zhao, J.: Stalagmite evidence for the onset of the Last Interglacial in southern Europe at $129 \pm 1 \mathrm{ka}$, Geophys. Res. Lett., 32, doi:10.1029/2005GL024658, 2005.

Dumurdzanov, N., Serafimovski, T., and Burchfiel, B.: Cenozoic 
tectonics of Macedonia and its relation to the South Balkan extensional regime, Geosphere, 1, 1-22, 2005.

Gawthorpe, R., and Leeder, M.: Tectono-sedimentary evolution of active extensional basins, Basin Res., 12, 195-218, 2000.

Genner, M., Knight, M., Haesler, M., and Turner, G.: Establishment and expansion of Lake Malawi rock fish populations after a dramatic Late Pleistocene lake level rise, Mol. Ecol., 19, 170-182, doi: 10.1111/j.1365-294X.2009.04434.x, 2010.

Gilbert, G.: Lake Bonneville, United States Geological Survey, 438 pp., 1890.

Hauffe, T., Albrecht, C., Schreiber, K., Birkhofer, K., Trajanovski, S., and Wilke, T.: Spatially explicit analyses of gastropod biodiversity in ancient Lake Ohrid, Biogeosciences Discuss., 7, 49534985, doi:10.5194/bgd-7-4953-2010, 2010.

Hayes, A., Kucera, M., Kallel, N., Sbaffi, L., and Rohling, E.: Glacial Mediterranean sea surface temperatures based on planktonic foraminiferal assemblages, Quaternary Sci. Rev., 24, 9991016, 2005.

Helland-Hansen, W. and Martinsen, O.: Shoreline trajectories and sequences: description of variable depositional-dip scenarios, J. Sediment. Res. B., 66, 670-688, 1996.

Hughes, P., Woodward, J., and Gibbard, P.: Quaternary glacial history of the Mediterranean mountains, Prog. Phys. Geog., 30, 334-364, doi: 10.1191/0309133306pp481ra, 2006.

Hunt, D. and Tucker, M.: Stranded parasequences and the forced regressive wedge systems tract: deposition during base-level fall, Sediment. Geol., 81, 1-9, 1992.

Johnson, T., Scholz, C., Talbot, M., Kelts, K., Ricketts, R., Ngobi, G., Beuning, K., Ssemmanda, I., and McGill, J.: Late Pleistocene desiccation of Lake Victoria and rapid evolution of cichlid fishes, Science, 273, 1091-1093, doi:10.1126/science.273.5278.1091, 1996.

Keller, J., Ryan, W., Ninkovich, D., and Altherr, R.: Explosive volcanic activity in the Mediterranean over the past 200,000 $\mathrm{yr}$ as recorded in deep-sea sediments, Bull. Geol. Soc. Am., 89, 591604, 1978.

Kraml, M.: Laser-Ar/Ar-Datierungen and distalen marinen Tephren des jung-quartären mediterranen Vulkanismus (Ionisches Meer, M25/4), Ph. D., Albert-Ludwings-Universität Freiburg, Freiburg, 216 pp., 1997.

Lamothe, M., Auclair, M., Hamzaoui, C., and Huot, S.: Towards a prediction of long-term anomalous fading of feldspar IRSL, Radiat. Meas., 37, 493-498, 2003.

Lézine, A., Von Grafenstein, U., Andersen, N., Belmecheri, S., Bordon, A., Caron, B., Cazet, J., Erlenkeuser, H., Fouache, E., and Grenier, C.: Lake Ohrid, Albania, provides an exceptional multiproxy record of environmental changes during the last glacialinterglacial cycle, Palaeogeogr. Palaeocl., 287, 116-127, 2010.

Magny, M., Peyron, O., Gauthier, E., Rouèche, Y., Bordon, A., Billaud, Y., Chapron, E., Marguet, A., Pétrequin, P., and Vannière, B.: Quantitative reconstruction of climatic variations during the Bronze and early Iron ages based on pollen and lake-level data in the NW Alps, France, Quatern. Int., 200, 102-110, 2009.

Marino, G., Rohling, E., Sangiorgi, F., Hayes, A., Casford, J., Lotter, A., Kucera, M., and Brinkhuis, H.: Early and middle Holocene in the Aegean Sea: interplay between high and low latitude climate variability, Quaternary Sci. Rev., 28, 3246-3262, 2009.

Martens, K.: Speciation in ancient lakes, Trends in Ecology \& Evo- lution, 12, 177-182, 1997.

Martrat, B., Grimalt, J., Lopez-Martinez, C., Cacho, I., Sierro, F., Flores, J., Zahn, R., Canals, M., Curtis, J., and Hodell, D.: Abrupt temperature changes in the Western Mediterranean over the past 250000 years, Science, 306, 1762, 2004.

Matter, M., Anselmetti, F. S., Jordanoska, B., Wagner, B., Wessels, M., and Wüest, A.: Carbonate sedimentation and effects of eutrophication observed at the Kališta subaquatic springs in Lake Ohrid (Macedonia), Biogeosciences Discuss., 7, 47154747, doi:10.5194/bgd-7-4715-2010, 2010.

Matzinger, A., Spirkovski, Z., Patceva, S., and Wuest, A.: Sensitivity of ancient Lake Ohrid to local anthropogenic impacts and global warming, J. Great Lakes Res., 32, 158-179, 2006.

Matzinger, A., Schmid, M., Veljanoska-Sarafiloska, E., Patceva, S., Guseska, D., Wagner, B., Müller, B., Sturm, M., and Wüest, A.: Eutrophication of ancient Lake Ohrid: Global warming amplifies detrimental effects of increased nutrient inputs, Limnol. Oceanogr., 52, 338-353, 2007.

Moernaut, J., Verschuren, D., Charlet, F., Kristen, I., Fagot, M., and Batist, M. D.: The seismic-stratigraphic record of lake-level fluctuations in Lake Challa: Hydrological stability and change in equatorial East Africa over the last $140 \mathrm{kyr}$, Earth Planet Sc. Lett., 290, 214-223, doi:10.1016/j.epsl.2009.12.023, 2010.

Paterne, M., Guichard, F., and Labeyrie, J.: Explosive activity of the South Italian volcanoes during the past 80,000 years as determined by marine tephrochronology, J. Volcanol. Geoth. Res., 34, 153-172, 1988.

Peyron, O., Guiot, J., Cheddadi, R., Tarasov, P., Reille, M., de Beaulieu, J., Bottema, S., and Andrieu, V.: Climatic reconstruction in Europe for $18000 \mathrm{yr}$ BP from pollen data, Quaternary Res., 49, 183-196, 1998.

Pirmez, C., Pratson, L., and Steckler, M.: Clinoform development by advection-diffusion of suspended sediment: Modeling and comparison to natural systems, J. Geophys. Res.-Sol. Ea., 103, 24141-24157, 1998.

Popovska, C. and Bonacci, O.: Basic data on the hydrology of Lakes Ohrid and Prespa, Hydrol. Process., 21, 658-664, 2007.

Posamentier, H., Allen, G., James, D., and Tesson, M.: Forced regressions in a sequence stratigraphic framework: concepts, examples, and exploration significance, AAPG Bull., 76, 16871687, 1992.

Preusser, F., Degering, D., Fuchs, M., Hilgers, A., Kadereit, A., Klasen, N., Krbetschek, M., Richter, D., and Spencer, J.: Luminescence dating: Basics, methods and applications, Quaternary Science Journal (Eiszeitalter und Gegenwart), 57, 95-149, 2008.

Schellmann, G., Beerten, K., and Radtke, U.: Electron spin resonance (ESR) dating of Quaternary materials, Eiszeitalter und Gegenwart, 57, 150-178, 2008.

Scholz, C. and Rosendahl, B.: Low lake stands in Lakes Malawi and Tanganyika, East Africa, delineated with multifold seismic data, Science, 240, 1645-1648, 1988.

Sclater, J. and Christie, P.: Continental stretching: an explanation of the post-mid-Cretaceous subsidence of the central North Sea basin, J. Geophys. Re., 85, 3711-3739, 1980.

Spirkovski, Z., Avramovski, O., and Kodzoman, A.: Watershed management in the Lake Ohrid region of Albania and Macedonia, Lakes \& reservoirs: research and management, 6, 237-242, 2001.

Stankovic, S.: The Balkan Lake Ohrid and Its Living World, W. 
Junk, 357 pp., 1960.

Sturmbauer, C., Baric, S., Salzburger, W., Ruber, L., and Verheyen, E.: Lake level fluctuations synchronize genetic divergences of cichlid fishes in African lakes, Mol. Biol. Evol., 18, 144-154, 2001.

Sulpizio, R., Zanchetta, G., Paterne, M., and Siani, G.: A review of tephrostratigraphy in central and southern Italy during the last $65 \mathrm{ka}$, Il Quaternario, 16, 91-108, 2003.

Sulpizio, R., Zanchetta, G., D’Orazio, M., Vogel, H., and Wagner, B.: Tephrostratigraphy and tephrochronology of lakes Ohrid and Prespa, Balkans, Biogeosciences, 7, 3273-3288, doi:10.5194/bg-7-3273-2010, 2010.

Susnik, S., Knizhin, I., Snoj, A., and Weiss, S.: Genetic and morphological characterization of a Lake, J. Fish Biol., 68, 2-23, 2006.

Tzedakis, P., Frogley, M., and Heaton, T.: Last Interglacial conditions in southern Europe: evidence from Ioannina, northwest Greece, Global Planet. Change, 36, 157-170, 2003.

Vogel, H., Wagner, B., Zanchetta, G., Sulpizio, R., and Rosén, P.: A paleoclimate record with tephrochronological age control for the last glacial-interglacial cylce from Lake Ohrid, Albania and Macedonia, J. Paleolimnol., doi:10.1007/s10933-009-9404x, 2010a.

Vogel, H., Zanchetta, G., Sulpizio, R., Wagner, B., and Nowaczyk, N.: A tephrostratigraphic record for the last glacial-interglacial cycle from Lake Ohrid, Albania and Macedonia., J. Quaternary Sci., 25, 320-338, 2010b.
Wagner, B., Reicherter, K., Daut, G., Wessels, M., Matzinger, A., Schwalb, A., Spirkovski, Z., and Sanxhaku, M.: The potential of Lake Ohrid for long-term palaeoenvironmental reconstructions, Palaeogeogr. Palaeocl., 259, 341-356, 2008a.

Wagner, B., Sulpizio, R., Zanchetta, G., Wulf, S., Wessels, M., Daut, G., and Nowaczyk, N.: The last 40 ka tephrostratigraphic record of Lake Ohrid, Albania and Macedonia: a very distal archive for ash dispersal from Italian volcanoes, J. Volcanol. Geoth. Res., 177, 71-80, 2008b.

Wagner, B., Lotter, A., Nowaczyk, N., Reed, J., Schwalb, A., Sulpizio, R., Valsecchi, V., Wessels, M., and Zanchetta, G.: A 40,000-year record of environmental change from ancient Lake Ohrid (Albania and Macedonia), J. Paleolimnol., 41, 407-430, 2009.

Wallinga, J., Bos, A., Dorenbos, P., Murray, A., and Schokker, J.: A test case for anomalous fading correction in IRSL dating, Quat. Geochronol., 2, 216-221, 2007.

Wessel, P. and Smith, W.: Free software helps map and display data, Eos Trans. AGU, 72, 445-446, 1991.

Zanchetta, G., Sulpizio, R., Giaccio, B., Siani, G., Paterne, M., Wulf, S., and D'Orazio, M.: The Y-3 tephra: A Last Glacial stratigraphic marker for the central Mediterranean basin, J. Volcanol. Geoth. Res., 177, 145-154, 2008. 